\title{
Identification of SARS-CoV-2-specific immune alterations in acutely ill
}

\section{patients}

Rose-Marie Rébillard ${ }^{1,4 \#}$, Marc Charabati ${ }^{1,4 \#}$, Camille Grasmuck ${ }^{1,4 \#}$, Abdelali Filali-Mouhim ${ }^{4}$,

Olivier Tastet ${ }^{4}$, Nathalie Brassard ${ }^{4}$, Audrey Daigneault ${ }^{4}$, Lyne Bourbonnière ${ }^{4}$, Renaud Balthazard $^{1,4}$, Ana Carmena Moratalla ${ }^{1,4}$, Yves Carpentier Solorio ${ }^{1,4}$, Negar Farzam-kia ${ }^{1,4}$, Antoine Philippe Fournier ${ }^{1,4}$, Elizabeth Gowing ${ }^{1,4}$, Hélène Jamann ${ }^{1,4}$, Florent Lemaître ${ }^{1,4}$, Victoria Hannah Mamane $^{1,4}$, Karine Thai ${ }^{1,4}$, Jean-François Cailhier ${ }^{3,4}$, Nicolas Chomont ${ }^{2,4}$, Andrés Finzi ${ }^{2,4}$, Michaël Chassé $^{3,4}$, Madeleine Durand ${ }^{3,4}$, Nathalie Arbour ${ }^{1,4}$, Daniel E. Kaufmann ${ }^{3,4}$, Alexandre Prat ${ }^{1,4}$, and Catherine Larochelle ${ }^{1,4^{*}}$

${ }^{1}$ Department of Neurosciences, ${ }^{2}$ Microbiology-Infectiology-Immunology, and ${ }^{3}$ Medicine Université de Montréal, QC, Canada

${ }^{4}$ CRCHUM 900 St-Denis Street, Montreal, QC, Canada, H2X 0A9

\# These authors share the first author position for equal contribution.

*Corresponding author

Catherine Larochelle M.D. Ph.D.

Department of Neurosciences

Université de Montréal, CRCHUM

R09.424

900 St-Denis Street, Montréal (Québec), Canada H2X 0A9

Phone: 514-890-8000 ext: 15370

Email: catherine.larochelle.chum@ssss.gouv.qc.ca 
medRxiv preprint doi: https://doi.org/10.1101/2020.12.21.20248642; this version posted December 22, 2020. The copyright holder for this preprint (which was not certified by peer review) is the author/funder, who has granted medRxiv a license to display the preprint in perpetuity. All rights reserved. No reuse allowed without permission.

Abstract: 198 words

Main body of the manuscript: 6723 words

Number of tables: 3

Number of figures: 5

Supplemental material: Supplemental Table 1-4, Supplemental Figure 1-4

Total number of words including references, tables and figure legends (manuscript and supplemental material): 11856 words

Running title: SARS-CoV-2-specific immune alterations 
medRxiv preprint doi: https://doi.org/10.1101/2020.12.21.20248642; this version posted December 22, 2020. The copyright holder for this preprint (which was not certified by peer review) is the author/funder, who has granted medRxiv a license to display the preprint in perpetuity.

\begin{abstract}
Dysregulated immune profiles have been described in symptomatic SARS-CoV-2-infected patients. Whether the reported immune alterations are specific to SARS-CoV-2 infection or also triggered by other acute illnesses remains unclear. We performed flow cytometry analysis on fresh peripheral blood from a consecutive cohort of i) patients hospitalized with acute SARS-CoV-2 infection; ii) patients of comparable age/sex hospitalized for other acute disease (SARS-CoV-2 negative); and iii) healthy controls. Using both data-driven and hypothesis-driven analyses, we found several dysregulations in immune cell subsets (e.g. decreased proportion of T cells) that are similarly associated with acute SARS-CoV-2 infection and non-COVID-19 related acute illnesses. In contrast, we identified specific differences in myeloid and lymphocyte subsets that are associated with SARS-CoV-2 status (e.g. elevated proportion of ICAM-1 ${ }^{+}$mature/activated neutrophils, $\mathrm{ALCAM}^{+}$monocytes, and $\mathrm{CD} 38^{+} \mathrm{CD} 8^{+} \mathrm{T}$ cells). A subset of SARS-CoV-2-specific immune alterations correlated with disease severity, disease outcome at 30 days and mortality. Our data provides novel understanding of the immune dysregulation that are specifically associated with SARS-CoV-2 infection among acute care hospitalized patients. Our study lays the foundation for the development of specific biomarkers to stratify SARS-CoV-2 $2^{+}$patients at risk of unfavorable outcome and uncover novel candidate molecules to investigate from a therapeutic perspective.
\end{abstract}


medRxiv preprint doi: https://doi.org/10.1101/2020.12.21.20248642; this version posted December 22, 2020. The copyright holder for this

\section{Introduction}

The severe acute respiratory syndrome coronavirus 2 (SARS-CoV-2) that causes the coronavirus19-disease (COVID-19) has now infected millions of people worldwide and caused the death of over 1 million patients (WHO operational update on November $6^{\text {th }} 2020$ ). The spectrum of clinical manifestations in SARS-CoV-2-infected patients (SARS-CoV-2 ${ }^{+}$) ranges from asymptomatic to severe acute respiratory distress syndrome (ARDS) and multiple organ involvement (1). Increasing evidence supports that the immune reaction plays a central role in COVID-19 severity and outcome. Therefore, it is essential to understand immune responses generated in COVID-19 to stratify patients at higher risk of unfavorable outcome and identify novel therapeutic targets. Several risk factors for negative clinical outcome have been identified $(2,3)$ but the underlying mechanisms of effective vs. impaired/deleterious immune responses to SARS-CoV-2 remain unclear.

Age is the greatest risk factor for COVID-19 severity and mortality (2-6). Obesity and cardiovascular comorbidities such as high blood pressure and diabetes also significantly increase the risk of severe clinical course in SARS-CoV-2-infected individuals $(3,4,6,7)$. Notably, each of these risk factors -age, obesity, diabetes and cardiovascular comorbidities- is associated with alterations in immune responses and a state of chronic low-grade inflammation (8-10) that could contribute to the elevated morbidity and mortality in COVID-19, as in other infectious conditions (11-13). Dysregulations of the immune profile in SARS-CoV-2-infected hospitalized patients (COVID-19) include elevated levels of circulating IL-6 and decreased peripheral lymphocytes/neutrophils ratios, which are predictive of worse clinical outcome $(7,14,15)$. Accumulating evidence suggest that both hyperactivation and exhaustion of different $\mathrm{T}$ and $\mathrm{B}$ cell subsets characterize COVID-19 $(7,14,16)$. A state of activation of CD4 ${ }^{+} \mathrm{T}$ cells with an increased 
medRxiv preprint doi: https://doi.org/10.1101/2020.12.21.20248642; this version posted December 22, 2020. The copyright holder for this preprint (which was not certified by peer review) is the author/funder, who has granted medRxiv a license to display the preprint in perpetuity. All rights reserved. No reuse allowed without permission.

$\mathrm{CD}^{+} / \mathrm{CD}^{+}$ratio has been recently linked to disease severity $(14,17)$. Whether the reported immune alterations are specific to SARS-CoV-2 infection or rather commonly triggered by a range of acute illnesses, especially in older subjects with pre-existing medical conditions, remains unknown. We performed a detailed characterization of circulating innate and adaptive immune cells from 50 SARS-CoV-2 ${ }^{+}$patients (47 hospitalized for COVID-19, three asymptomatic nosocomial infection) in comparison with 22 patients similar in regards to sex and age hospitalized for other acute illnesses (SARS-CoV-2 ${ }^{\text {neg }}$ ) and 49 healthy controls (HC). We found a SARS-CoV2-specific immune profile that could identify relevant therapeutic targets related to severity and outcome in COVID-19 patients. 
medRxiv preprint doi: https://doi.org/10.1101/2020.12.21.20248642; this version posted December 22, 2020. The copyright holder for this preprint (which was not certified by peer review) is the author/funder, who has granted medRxiv a license to display the preprint in perpetuity.

\section{Results}

SARS-CoV $-2^{+}$and SARS-CoV-2neg groups of hospitalized patients have similar prevalence of comorbidities, severity of disease and outcome at 30 days

To investigate SARS-CoV-2-triggered alterations in the peripheral immune system, we performed an extensive immune profiling of whole blood obtained from hospitalized patients and HC. Inclusion criteria for hospitalized participants included a nasopharyngeal swab SARS-CoV-2 PCR test conducted because of symptoms compatible with COVID-19, or because they were considered at risk of acute SARS-CoV-2 infection. Patients were classified as SARS-Cov-2 ${ }^{+}$patients or SARS-CoV-2 $2^{\text {neg }}$ patients based on the test results. Mean age and sex ratio were similar in SARS-CoV $-2^{+}$and SARS-CoV-2 ${ }^{\text {neg }}$ hospitalized patients' groups, while $\mathrm{HC}$ were younger and included a higher proportion of women (Table 1). No significant differences were observed in numbers of comorbidities, history of cancer or organ transplant between the SARS-CoV-2 ${ }^{+}$and SARS-CoV-2 ${ }^{\text {neg }}$ hospitalized patients (Table 1). Most hospitalized patients presented at least one comorbidity regardless of coronavirus status. A greater proportion of SARS-CoV $-2^{+}$subjects had comorbidities associated with risk for severe COVID-19 (obesity, chronic renal insufficiency and type 2 diabetes) compared to SARS-CoV-2 ${ }^{\text {neg }}$ patients, without reaching significance (Table 1). In contrast, respiratory and hepatic conditions were more frequent among SARS-CoV-2 ${ }^{\text {neg }}$ patients (not significant), probably reflecting the patient population in our hospital.

SARS-CoV $-2^{+}$and SARS-CoV-2 ${ }^{\text {neg }}$ hospitalized patients' groups exhibited comparable outcome at 30 days, mortality rate, and need for invasive ventilation during hospitalization (Table 2). Acute renal insufficiency was more frequent in SARS-CoV $-2^{+}$but did not reach significance. As previously reported, SARS-CoV-2 infection was associated with a high incidence of respiratory insufficiency and encephalopathy (delirium) in hospitalized patients $(2,3,18)$. The total burden of 
medRxiv preprint doi: https://doi.org/10.1101/2020.12.21.20248642; this version posted December 22, 2020. The copyright holder for this

medical complications during hospitalization and the average duration of invasive ventilation were elevated in SARS-CoV-2 $2^{+}$patients (Table 2). Of note, at time of baseline blood sampling, both groups of patients showed a similar proportion of intensive care unit (ICU) hospitalization and number of days in hospital (Supplemental Table 1). Association analyses among clinical parameters (Figure 1A) demonstrated that our two patient groups presented the expected relationships between age, comorbidities (past medical history: $\mathrm{PMH}$ ) and medical complications. Moreover, risk of death correlated with mechanical ventilation, respiratory insufficiency, and other medical complications. We also observed the expected association of SARS-CoV-2 status with typical COVID-19 symptoms at admission, as well as with delirium and respiratory insufficiency. Age, disease severity, and unfavorable outcome were associated but the overlap was only partial (Table 2).

\section{Dysregulation of peripheral immune cell subsets in SARS-CoV $-2^{+}$and SARS-CoV-2}

\section{hospitalized patients}

To compare the immune profiles of SARS-CoV $-2^{+}$and SARS-CoV $-2^{\text {neg }}$ hospitalized patients and HC, we performed three complementary flow cytometry staining panels on fresh whole blood samples and assessed the frequency of different subpopulations of lymphocytes, monocytes, dendritic cells and granulocytes. Our quality control analysis on the first 20 samples acquired in four batches over two weeks ruled out significant batch effects and validated the capture of reproducible inter-individual variation (example IgD detection, Figure 1B). We used two analysis approaches: i) a data-driven approach, using the PhenoGraph (19) and FlowSOM (20) algorithms to cluster similar cells in an unbiased manner (Figure 1C-E), and ii) a hypothesis-driven analysis with conventional gating strategy. We focused our analysis on cell subsets representing at least $1 \%$ of major cell subsets. Using the data-driven approach, we identified 21 cell clusters in the 
medRxiv preprint doi: https://doi.org/10.1101/2020.12.21.20248642; this version posted December 22, 2020. The copyright holder for this

monocyte and neutrophil gate (gating according to granularity and size excluding lymphocytes, 14 markers) for the first staining panel (S1) (Figure 1C and Supplemental Figure 1A), 31 cell clusters in the monocyte and lymphocyte gates for the dendritic cell/NK cell-oriented panel (S2, 14 markers, gating excluding granulocytes) (Figure 1D and Supplemental Figure 1A) and 18 cell clusters in the monocyte and lymphocyte gate for the lymphocyte-oriented panel (S3, 13 markers, gating excluding granulocytes) (Figure 1E and Supplemental Figure 1A). The distribution of clustered populations as illustrated by the Uniform Manifold Approximation and Projection (UMAP) algorithm shows distinct populations and relative abundance of these subsets in blood samples.

We compared the abundance of these 70 identified cell clusters in the three donor groups: HC, SARS-CoV $-2^{+}$hospitalized patients and SARS-CoV $-2^{\text {neg }}$ hospitalized patients. Only populations with at least one significant (adjusted $\mathrm{p}$ value $<0.05$ ) difference between two groups were considered. We identified 13 immune subpopulations that were specifically increased or decreased in samples from SARS-CoV $-2^{+}$hospitalized patients compared to both $\mathrm{HC}$ and SARS-CoV-2 ${ }^{\text {neg }}$ hospitalized patients (Figure 2A, populations identified in green) and 16 subpopulations that were similarly altered in both groups of hospitalized patients compared to HC (Figure 2A, populations identified in blue). The distribution of some of these subpopulations showing significant differences between our groups are illustrated (Figure 2B and C). We observed alterations in the abundance of peripheral immune cell subpopulations (e.g. T cells, B cells, myeloid/monocytes and neutrophils) compared to $\mathrm{HC}$ in the acutely ill groups regardless of SARS-CoV-2 status, for example a subset of CD19 ${ }^{+}$B cells (S2_Pop30) (Figure 2B). In contrast, the abundance of specific immune cell subsets was elevated or reduced in SARS-CoV-2 $2^{+}$ 
medRxiv preprint doi: https://doi.org/10.1101/2020.12.21.20248642; this version posted December 22, 2020. The copyright holder for this

compared to SARS-CoV-2 ${ }^{\text {neg }}$ hospitalized patients, for example a subset of $\mathrm{CD} 27^{+} \mathrm{CD} 8^{+} \mathrm{T}$ cells (S3_Pop17) (Figure 2C).

To corroborate these observations, we used a conventional approach to analyse the different subsets of granulocytes, myeloid/monocytes and lymphocytes. Only those with significant differences (adjusted $\mathrm{p}$ value $<0.05)$ according to status $\left(\mathrm{HC}\right.$ or SARS-CoV-2 ${ }^{\text {neg }}$ or SARS-CoV $-2^{+}$) are presented in Figure 2D. In line with the results of the unbiased analysis, we found several immune cell populations that differed significantly from $\mathrm{HC}$ in hospitalized patients but are associated with acute illness rather than being specific for COVID-19. Of note, the differences observed according to status (HC or SARS-CoV $-2^{\text {neg }}$ or SARS-CoV $-2^{+}$) in general immune cell populations (e.g. lymphocytes) were consistent across the different panels (Figure 2D). Importantly, we were able to identify significant and specific alterations in samples from SARS-CoV $-2^{+}$compared to both $\mathrm{HC}$ and SARS-CoV $-2^{\text {neg }}$ hospitalized patients, for example upregulation of PD-1 on T cells (particularly $\mathrm{CD}^{+} \mathrm{T}$ cells) (Figure 2D populations indicated in bold).

Neutrophilia and lymphopenia predict outcome but are associated with severity of illness and age rather than specific to $S A R S-C o V-2$ infection

Previous studies have identified lymphopenia and neutrophilia as predictive of worse clinical outcome in SARS-CoV-2 infection $(8,15,16)$. Compared to $\mathrm{HC}$, we detected a significantly increased proportion of neutrophils, and a corresponding decreased proportion of lymphocytes $\left(\mathrm{CD}^{+} \mathrm{T}\right.$ cells and $\mathrm{CD} 19^{+} \mathrm{B}$ cells), in samples from hospitalized patients (Figure 2 and 3). However, these changes were not specific for SARS-CoV-2 infection and were observed in both hospitalized groups. As age represents an important factor shaping the immune system as well as 
medRxiv preprint doi: https://doi.org/10.1101/2020.12.21.20248642; this version posted December 22, 2020. The copyright holder for this

one of the greatest risk factors for COVID-19 severity and mortality (2-6), we also compared these immune populations in $\mathrm{HC}$ and younger patients ( $<60$ y.o.), as well as in older patients ( $\geq 60$ y.o.). We observed that lymphopenia and neutrophilia were most striking in older patients (Figure 3A) and in relation to the severity of the medical condition, independently of SARS-CoV-2 status or other acute illness status (Figure 3B). While not specific for SARS-CoV-2 infection, neutrophilia and lymphopenia, as well as a low proportion of $\mathrm{CD}^{+}$but not $\mathrm{CD} 19^{+}$cells, were in addition strongly tied to outcome at 30 days (Figure 3C). Within the neutrophil compartment, we observed a statistically significant shift from $\mathrm{CD} 16^{\text {hi }} \mathrm{CD} 15^{+}$to $\mathrm{CD} 16^{\text {lo }} \mathrm{CD} 15^{+}$neutrophils in SARS-CoV-2 $2^{+}$ and SARS-CoV-2 ${ }^{\text {neg }}$ patients compared with HCs (Figure 2D and 3A and Supplemental Figure 3), but no difference when comparing SARS-CoV $-2^{+}$with SARS-CoV-2 ${ }^{\text {neg }}$ patients and no association with disease severity (Figure 3B), which demonstrates that this shift was not specific to COVID19. Within the $\mathrm{CD}^{+} \mathrm{T}$ cell compartment, the $\mathrm{CD} 4^{+} / \mathrm{CD} 8^{+}$ratio increased with older age as expected but was not different between groups of similar age, while $\mathrm{CD}^{+} \gamma \delta \mathrm{T}$ cells and iNKT cells were reduced in SARS-CoV $-2^{+}$samples compared to $\mathrm{HC}$ but not different from SARS-CoV$2^{\text {neg }}$ samples in hospitalized patients nor associated with disease severity (Figure 3A-B).

The frequency of NK cells was reduced in both groups of hospitalized patients compared to HC (Figure 2D), especially in individuals with severe medical condition (COVID-19 or other acute illness), and was significantly lower in SARS-CoV $-2^{+}$patients showing a worse clinical outcome at 30 days (Figure 3A-C). Finally, as previously reported (21), we observed a decreased frequency of $\mathrm{CD} 123^{+}$and $\mathrm{CD} 11 \mathrm{c}^{+}$cells among the $\mathrm{CD} 3^{\text {neg }} \mathrm{CD} 19^{\text {neg }} \mathrm{CD} 14^{\text {neg }} \mathrm{CD} 56^{\text {neg }}$ cells (presumably pDCs and cDCs) in the peripheral blood of SARS-CoV $-2^{+}$patients but this was not significantly different in SARS-CoV-2 ${ }^{\text {neg }}$ acutely ill patients. The frequency of monocytes was similar in HC, SARS-CoV-2 $2^{\text {neg }}$ and SARS-CoV-2 $2^{+}$patients (Fig. 3A) but HLA-DR expression on CD14 $4^{+}$ 
medRxiv preprint doi: https://doi.org/10.1101/2020.12.21.20248642; this version posted December 22, 2020. The copyright holder for this

monocytes was significantly reduced in both groups of hospitalized patients as compared to HC (Fig. 2D), indicating a possible monocyte exhaustion, a phenomenon typically observed following acute intense monocyte inflammation as seen for example in sepsis (22). Altogether, our data confirm previous reports linking neutrophilia and lymphopenia with severe COVID-19 and worse outcome; however, we demonstrate that these changes are associated with age and severity of the medical condition rather than being specific for SARS-CoV-2 infection.

\section{SARS-CoV-2 infection is associated with a significantly higher proportion of circulating pro- myelocyte and mature neutrophils but not activated neutrophils}

As significant neutrophilia was observed in both SARS-CoV-2 ${ }^{\text {neg }}$ and SARS-CoV $-2^{+}$patients compared to $\mathrm{HC}$, we investigated whether specific neutrophil subsets within the granulocytes' gate $\left(\mathrm{CD} 14^{\text {neg }}\right.$ cells in the neutrophil FSC-SSC gate) were specifically altered in SARS-CoV-2 ${ }^{+}$ patients. The proportion of promyelocytes $\left(\mathrm{CD} 38^{+}\right)$, precursors of granulocytes, was significantly higher in SARS-CoV-2 $2^{+}$patients compared to SARS-CoV-2 ${ }^{\text {neg }}$ patients and HC (Figure 2D); this increased percentage of promyelocytes was however not significantly different according to severity, and did not distinguish outcome at 30 days (Figure 4A-C). In parallel, the frequency of mature neutrophils $\left(\mathrm{CD} 16^{\mathrm{hi}} \mathrm{CD} 15^{+} \mathrm{CD} 11 \mathrm{~b}^{\mathrm{hi}} \mathrm{CD} 62 \mathrm{~L}^{\mathrm{hi}}\right)$ was specifically increased in the peripheral blood in SARS-CoV-2 $2^{+}$patients (Figure 2D), while that of activated neutrophils $\left(\mathrm{CD} 16^{\text {hi }} \mathrm{CD} 15^{+} \mathrm{CD} 11 \mathrm{~b}^{\text {hi }} \mathrm{CD} 62 \mathrm{~L}^{\text {lo }}\right)$ was lower, but these subsets were not associated with severe COVID-19 (Figure 4B and Supplemental Figure 3B). Our results suggest that specific stages of neutrophils were over-represented in peripheral blood of SARS-CoV-2 ${ }^{+}$patients, while most circulating activated neutrophils might have already infiltrated organs (e.g. lungs), died of over- 
medRxiv preprint doi: https://doi.org/10.1101/2020.12.21.20248642; this version posted December 22, 2020. The copyright holder for this

stimulation (NETosis) following acute infection and/or were immunosuppressed as previously reported (23).

Expression of MHC-related molecule CD1a on monocytes is associated with SARS-CoV-2 status, severity and outcome

We also investigated whether specific subpopulations of antigen presenting cells (APC) were altered in patients as these could secrete multiple inflammatory mediators (cytokines, myeloperoxidases, reactive oxidative species, etc.) and present antigen to $\mathrm{T}$ cells. Within the monocyte compartment, monocytes bearing CD16 (FC $\gamma$ IIIR) are associated with secretion of proinflammatory cytokine TNF, antigen-presenting capacity and tissue homing (24). The proportion of classical $\mathrm{CD} 14^{\mathrm{hi}} \mathrm{CD} 16^{\text {neg }}$ monocytes was specifically reduced in SARS-CoV-2 ${ }^{+}$patients compared to $\mathrm{HC}$ and SARS-CoV-2 $2^{\text {neg }}$ patients; in contrast, the frequency of intermediate $\mathrm{CD} 14^{\text {hi }} \mathrm{CD} 16^{+}$monocytes was specifically augmented in SARS-CoV-2 $2^{+}$patients (Figure $2 \mathrm{D}$ and 4A), but was not significantly associated with severity (Supplemental Figure 3B) or outcome (data not shown). Notably, the proportion of $\mathrm{CD}_{1} 4^{+}$monocytes expressing CD1a, which is implicated in lipid antigens presentation to T cells and is induced on $\mathrm{CD} 14^{+}$monocytes exposed to IL-4 and GM-CSF (25), was also increased in SARS-CoV $-2^{+}$patients compared to both $\mathrm{HC}$ and SARS-CoV-2 ${ }^{\text {neg }}$ patients regardless of age (Figure $2 \mathrm{D}$ and $4 \mathrm{~A}$ ). Moreover, $\mathrm{CD} 1 \mathrm{a}^{+} \mathrm{CD} 14^{+}$ monocytes were more prevalent in SARS-CoV-2 $2^{+}$patients exhibiting severe symptoms and in SARS-CoV $-2^{+}$patients experiencing unfavorable outcome at 30 days. Overall, our results suggest that in response to SARS-CoV-2 infection, specific subsets of peripheral blood antigen presenting cells are altered. 
medRxiv preprint doi: https://doi.org/10.1101/2020.12.21.20248642; this version posted December 22, 2020. The copyright holder for this

\section{B cells subsets are altered in SARS-CoV-2 infection}

B cell-depleting therapies are associated with a higher risk of severe COVID-19 course (26) and several publications support the contribution of neutralizing antibodies to the immune response in SARS-CoV-2 infection (27-30) As we detected a reduction in peripheral blood B cells in hospitalized patients compared to HCs, we assessed the frequency of specific B cell subpopulations in our cohort using CD5, as well as CD27 and IgD as subset markers. We found that the proportion of B cells expressing CD5 was significantly reduced in SARS-CoV-2 ${ }^{\text {neg }}$ and SARS-CoV $-2^{+}$patients compared to HC (Figure 2D), but this reduction was more pronounced in SARS-CoV $-2^{+}$patients, especially in patients experiencing a severe clinical course or showing an unfavorable clinical outcome at 30 days (Figure 4A-C). Notably, $\mathrm{CD}^{+} \mathrm{B}$ cells play a crucial role in innate immunity (31) and include natural polyreactive antibody-producing cells (32) and IL-10producing regulatory cells (33). Analysis of B cells according to their expression of IgD and CD27 revealed a significantly higher proportion of $\operatorname{IgD}{ }^{\text {neg }} C D 27^{\text {neg }} B$ cells in SARS-CoV $-2^{+}$patients compared to $\mathrm{HC}$ and to SARS-CoV-2 ${ }^{\text {neg }}$ patients (Figure 2D); this increase was more pronounced in older patients (Figure 4A) but did not differ according to severity (Supplemental Figure 3B) or outcome (data not shown). This $\operatorname{IgD}^{\text {neg }} \mathrm{CD} 27^{\text {neg }} \mathrm{B}$ cell subset is expanded in the peripheral blood of patients with inflammatory diseases, viral infections and upon aging (34-37). In contrast, the other subpopulations $\left(\mathrm{CD} 27^{+} \operatorname{IgD}{ }^{\text {neg }}, \mathrm{CD} 27^{+} \mathrm{IgD}^{+}, \mathrm{CD} 27^{\text {neg }} \operatorname{IgD}^{+}\right)$were either similarly prevalent in all three groups or comparable between SARS-CoV-2 neg and SARS-CoV-2 ${ }^{+}$patients (Figure 2D and Supplemental Figure 3A). Further classification of subsets of naïve, unswitched memory, switched memory and double negative B cells according to CD24 and CD38 expression did not reveal expression patterns specific to SARS-CoV-2 infection except for a reduction in the abundance of pre-switched/resting memory B cells $\left(\mathrm{CD} 27^{+} \operatorname{IgD}^{\text {neg }} \mathrm{CD} 24^{+} \mathrm{CD} 38^{+/ l o}\right)$ that was more 
medRxiv preprint doi: https://doi.org/10.1101/2020.12.21.20248642; this version posted December 22, 2020. The copyright holder for this

pronounced in older SARS-CoV-2 $2^{+}$patients (Figure 2D and Supplemental Figure 3A) but was not associated with disease severity $(p=0.41)$ or outcome $(p=0.45)$. Overall, our results demonstrate alterations of specific $B$ cell subpopulations (reduced $\mathrm{CD}^{+}$and increased $\operatorname{IgD}^{\text {neg }} \mathrm{CD} 27^{\text {neg }}$ ) in SARS-CoV $-2^{+}$patients compared to the other groups, suggesting a shift towards a proinflammatory B cell profile.

Activated $\mathrm{CD} \mathrm{S}^{+} \mathrm{CDS}^{+} \mathrm{T}$ cells and $\mathrm{PD}-1^{+} \mathrm{CD}^{+} \mathrm{T}$ cells characterize $\mathrm{SARS}-\mathrm{CoV}-2^{+}$patients and are associated with outcome

We investigated whether multiple markers (PD-1, CD38, CD27, CD56) triggered on activated or memory $\mathrm{T}$ cell subpopulations and associated with antiviral responses are altered in SARS-CoV2 ${ }^{+}$ patients (Figure 2D). CD38 has been linked to T cell functions such as protection from cell death (38) and high suppressive activity by regulatory T cells, and to disease progression in HIV patients (38). We found that CD38 expression was strongly up-regulated on CD8 ${ }^{+} \mathrm{T}$ cells in SARS-CoV-2 ${ }^{+}$ patients compared to SARS-CoV-2 ${ }^{\text {neg }}$ patients and HC (Figure 2D) regardless of age (Figure 4A). Levels tended to be higher in severe COVID-19 compared to mild/moderate SARS-CoV-2 infection (Figure 4B). Importantly, the percentage of $\mathrm{CD} 38^{+} \mathrm{CD} 8^{+} \mathrm{T}$ cells was significantly higher in the worse outcome group at 30 days (Figure 4C). Our results suggest that an elevated frequency of $\mathrm{CD} 38^{+} \mathrm{CD}^{+} \mathrm{T}$ cells represents a biomarker for a protracted course of severe COVID-19 still requiring supplemental oxygenation at 30 days. We observed a significant reduction in the proportion of $\mathrm{CD}^{+} \mathrm{T}$ cells expressing CD38 in both SARS-CoV-2 ${ }^{\text {neg }}$ and SARS-CoV-2 $2^{+}$patients compared to HC (Figure 2D) without any significant association with age, severity or outcome (Supplemental Figure 3). 
medRxiv preprint doi: https://doi.org/10.1101/2020.12.21.20248642; this version posted December 22, 2020. The copyright holder for this

PD-1 is an immune checkpoint molecule associated with T cell activation and exhaustion (39). The proportion of PD-1-expressing $\mathrm{CD}^{+} \mathrm{T}$ cells and more specifically $\mathrm{CD} 4^{+} \mathrm{T}$ cells was elevated in both older and younger SARS-CoV $-2^{+}$patients compared to SARS-CoV-2 ${ }^{\text {neg }}$ hospitalized patients and $\mathrm{HC}$ (Figure 2D and 4A). PD-1 expression was not associated with disease severity among SARS-CoV-2 $2^{+}$samples (Figure 4B) but the percentage of PD $-1^{+} \mathrm{CD} 4^{+} \mathrm{T}$ cells was significantly elevated in SARS-CoV $-2^{+}$patients demonstrating an unfavorable outcome at 30 days (Figure 4C). Expression of PD-1 on $\mathrm{CD}^{+} \mathrm{T}$ cells was higher in SARS-CoV-2 ${ }^{+}$patients compared to $\mathrm{HC}$ but this was almost exclusively observed in older patients and did not significantly differ from SARS-CoV-2 ${ }^{\text {neg }}$ hospitalized patients (Supplemental Figure 3A). Finally, the percentage of $\mathrm{CD}^{+} \mathrm{T}$ cells expressing CD27 and CD56 were respectively reduced and increased compared to $\mathrm{HC}$, and showed a similar trend compared to SARS-CoV-2 ${ }^{\text {neg }}$ patients, but were not associated with severity (Figure 2D and Supplemental Figure 3A-B). Overall, our results show that CD38 on $\mathrm{CD}^{+} \mathrm{T}$ cells and PD-1 on $\mathrm{CD}^{+} \mathrm{T}$ cells were specifically altered in SARS-CoV-2 ${ }^{+}$patients and associated with outcome at 30 days.

\section{Up-regulation of specific trafficking molecules distinguishes SARS-CoV-2 infection, COVID-}

\section{9 severity and clinical outcome}

Diapedesis of circulating leukocytes is a crucial inflammatory step in immune responses that, when out of control, can cause serious collateral damage $(40,41)$. To determine whether COVID-19 affects the trafficking potential of circulating leukocytes, we assessed a selection of key trafficking molecules (ICAM-1, ALCAM, CCR2, CD11c) on the different immune cell populations. In granulocytes we observed that the proportion of mature and activated neutrophils expressing ICAM-1 (42) is increased in hospitalized patients compared to $\mathrm{HC}$ and more so in SARS-CoV-2 $2^{+}$ 
medRxiv preprint doi: https://doi.org/10.1101/2020.12.21.20248642; this version posted December 22, 2020. The copyright holder for this

patients (Figure 2D and 4A and Supplemental Figure 3), especially those exhibiting a severe disease and experiencing an unfavorable outcome at 30 days (Figure 4B-C). These data suggest that $\mathrm{ICAM}-1^{+}$neutrophils, which have been associated with dissemination of inflammation through reverse transendothelial migration, cellular aggregation and effector function (43-45), could participate to fuel the pro-inflammatory cascade observed in COVID-19.

Strikingly, the percentage of monocytes $\left(\mathrm{CD} 14^{+}\right)$expressing the cell adhesion molecule ALCAM was strongly up-regulated in SARS-CoV-2 $2^{+}$patients compared to both $\mathrm{HC}$ and SARS-CoV-2 ${ }^{\text {neg }}$ patients (Figure 2D and 4A). This increased frequency was found in younger and older patients and was significantly higher in patients with severe COVID-19 and elevated in patients who showed unfavorable outcome at 30 days (Figure 4B-C). ALCAM is associated with leukocyte transendothelial migration and with the stabilization of the immune synapse $(46,47)$. This suggest that monocytes from SARS-CoV $-2^{+}$patients could be poised to activate lymphocytes and interact with the endothelium, thus participating in the general inflammatory processes.

Inversely CCR2, a chemokine receptor implicated in recruitment of monocytes to pulmonary alveolar tissue (48), was expressed by a reduced percentage of monocytes $\left(\mathrm{CD} 14^{+}\right)$in SARS-CoV $-2^{+}$patients compared to SARS-CoV-2 ${ }^{\text {neg }}$ patients (Figure $2 \mathrm{D}$ and 4A). This reduction was not associated with disease severity but was significantly more pronounced in SARS-CoV-2 $2^{+}$ patients with an unfavorable outcome at 30 days (Fig. 4B-C). As the bronchoalveolar fluid from COVID-19 patients has been shown to contain abundant inflammatory monocyte-derived macrophages and CCR2 ligand CCL2 (49), the reduced proportion of CCR2 ${ }^{+}$monocytes in the periphery could result from preferential transmigration of these subsets in the inflamed lungs, or simply reflect the reduction in classical monocytes which also express CCR2. 
medRxiv preprint doi: https://doi.org/10.1101/2020.12.21.20248642; this version posted December 22, 2020. The copyright holder for this

Among T cells, CCR2 expression was also reduced in SARS-CoV-2 $2^{+}$patients (Figure 2D) but did not significantly correlate with severity or outcome (good vs. bad outcome: $\mathrm{CD} 4^{+} \mathrm{CCR} 2^{+} 14.42 \%$ \pm 1.11 vs $11.80 \% \pm 1.72 \mathrm{p}=0.24 ; \mathrm{CD}^{+} \mathrm{CCR} 2^{+} 8.53 \% \pm 1.07$ vs. $\left.7.09 \% \pm 1.32, \mathrm{p}=0.71\right)$. The frequency of $\mathrm{CD}^{+} \mathrm{T}$ cells bearing integrin $\beta 2 \mathrm{CD} 11 \mathrm{c}$ was significantly lower in the blood of SARS-CoV $-2^{+}$patients compared to SARS-CoV-2 ${ }^{\text {neg }}$ (Figure 2D and 4A), especially in severe cases (Supplemental Figure 3B), but did not correlate with outcome among SARS-CoV-2 ${ }^{+}$patients $(\mathrm{p}=0.33)$. Notably, this $\mathrm{T}$ cell subset has anti-viral properties and can accumulate in the lungs during infection (50), and can suppress pathogenic $\mathrm{T}$ cells in autoimmunity (51). The proportion of B cells expressing CD11c or ALCAM followed a similar pattern (Figure 2D), with a specific up-regulation of both markers on B cells from SARS-CoV-2+ especially in patients over 60 y.o. compared to $\mathrm{HC}$ and SARS-CoV-2 ${ }^{\text {neg }}$ patients; however, there was no significant difference between mild/moderate and severe COVID-19 symptoms (Supplemental Figure 3B) or according to outcome among SARS-CoV $-2^{+}$patients.

\section{Multivariate analysis confirms independent associations of identified immune cell populations} with SARS-CoV-2 status

Using random forest class prediction analysis (52), we explored whether the immune cell populations identified by the univariate non-parametric Kruskal-Wallis tests as being associated to SARS-CoV-2 status are also independently associated to status in a multivariate model. We confirmed that frequency of $\mathrm{ICAM}^{+}{ }^{+}$activated neutrophils, CCR2 ${ }^{+}, \mathrm{CD}^{+} \mathrm{a}^{+}$and $\mathrm{ALCAM}^{+}$ monocytes, $\mathrm{CD} 38^{+} \mathrm{CD} 8^{+} \mathrm{T}$ cells and $\mathrm{PD}-1^{+} \mathrm{CD} 4^{+} \mathrm{T}$ cells, were all among the top 30 important predictive features, as measured by the Gini importance index (Supplemental Figure 4)(52), to discern between $\mathrm{HC}$ and hospitalized patients. However, $\mathrm{CD} 5^{+} \mathrm{B}$ cells were not found to be of 
medRxiv preprint doi: https://doi.org/10.1101/2020.12.21.20248642; this version posted December 22, 2020. The copyright holder for this

high importance to distinguish between $\mathrm{HC}$ and $\mathrm{SARS}-\mathrm{CoV}-2^{+}$patients in this multivariate analysis. Of note, $\mathrm{HC}$ and SARS-CoV-2 $2^{+}$patients but not SARS-CoV-2 ${ }^{\text {neg }}$ patients were classified with a high accuracy. Such inaccuracy to classify SARS-CoV-2 ${ }^{\text {neg }}$ patients is probably due to the lower number of patients and the greater heterogeneity of diseases in this group.

COVID-19 mortality is associated with higher frequency of ICAM-1 ${ }^{+}$neutrophils, ALCAM monocytes and $\mathrm{CD} \mathrm{B}^{+} \mathrm{CDB}^{+} \mathrm{T}$ cells

We next determined whether the immune subpopulations we identified as dysregulated in hospitalized patients (24 populations) are associated with selected clinical parameters (Figure 5A). Sex, obesity and days since onset of symptoms did not show strong correlations with most immune parameters. While not specific to $\mathrm{SARS}-\mathrm{CoV}-2^{+}$patients, neutrophilia and lymphopenia, especially low $\mathrm{CD}^{+} \mathrm{T}$ cells count, were associated with medical complications, invasive ventilation and mortality in SARS-CoV-2 $2^{+}$patients. In addition, we found that most immune subpopulations specifically altered in SARS-CoV $-2^{+}$patients, and linked with severity and outcome, were similarly associated with medical complications, invasive ventilation and mortality (Figure 5A and Table 3). When looking specifically among severe COVID-19 patients requiring invasive ventilation, those who did not survive at 60 days had a significantly higher proportion of ICAM $-1^{+}$cells among activated and mature neutrophils (Figure 5B). In addition, deceased patients showed a higher proportion of monocytes expressing $\mathrm{ALCAM}^{+}$but a trend towards a reduced proportion expressing CCR2. Finally, a higher proportion of $\mathrm{CD} 38^{+} \mathrm{CD} 8^{+} \mathrm{T}$ cells (Figure $5 \mathrm{~A}-\mathrm{B}$ ) was observed in deceased severe COVID-19 patients compared to survivors. The other SARS$\mathrm{CoV}-2^{+}$specific dysregulated immune populations $\left(\mathrm{PD}-1^{+} \mathrm{CD} 4^{+} \mathrm{T}\right.$ cells, $\mathrm{CD} 5^{+}$on $\mathrm{B}$ cells, $\mathrm{CD} 1 \mathrm{a}^{+}$ 
medRxiv preprint doi: https://doi.org/10.1101/2020.12.21.20248642; this version posted December 22, 2020. The copyright holder for this

monocytes) were not significantly altered in deceased compared to survivors among severe COVID-19 patients (Table 3).

\section{Longitudinal analysis reveals increasing expression of CD38 and PD-1 on $T$ cells in patients} with unfavorable outcome

We were able to obtain follow-up samples at $24 \mathrm{~h}-72 \mathrm{~h}(\mathrm{t} 1)$ and at $4-8$ days (t2) after the baseline sample (t0) in a subset of SARS-CoV-2 ${ }^{+}$patients. Using a semi-parametric approach, Generalized Estimation Equations(53), we examined the trend over time in selected populations identified as specific to COVID-19. We did not observe a significant trend for ICAM- ${ }^{+}$neutrophils, or CD1a ${ }^{+}$ or $\mathrm{CCR} 2^{+}$monocytes, but we found that expression of ALCAM on monocytes was consistently and significantly lower over time in SARS-CoV $-2^{+}$showing a favorable outcome, but not in those showing an unfavorable outcome, at 30 days (Figure 5B). On the contrary, while the patients with a good outcome at 30 days did not show a significant change in the proportion of their B cells expressing CD5 over time, patients with a bad outcome almost all presented an increase at followup, starting from lower levels at first sampling. The proportion of $\mathrm{CD} 38^{+} \mathrm{CD} 8^{+} \mathrm{T}$ cells doubled over time in patients with COVID-19 regardless of outcome, therefore the increased frequency in patients with a bad outcome remained present at follow-up. Finally, while levels were not significantly different over time in SARS-CoV-2 $2^{+}$patients displaying a favorable outcome at 30 days, expression of PD-1 on $\mathrm{CD}^{+} \mathrm{T}$ significantly increased over time in most patients experiencing a bad outcome at 30 days and were strongly up-regulated at follow-up in 3/4 patients who did not survive. 
medRxiv preprint doi: https://doi.org/10.1101/2020.12.21.20248642; this version posted December 22, 2020. The copyright holder for this

\section{Discussion}

Understanding the specific immune responses associated with SARS-CoV-2 infection is paramount to the quest for targeted therapy. Many groups have reported immune dysregulations in circulating leukocytes from SARS-CoV-2 infected patients compared to healthy, often younger, subjects $(14-16,54,55)$. Most of them however did not investigate whether these changes were specific to SARS-CoV-2 infection or represent nonspecific remodeling of the immune system in response to stress inherent to acute illness. Indeed, other critical non-infectious medical conditions are associated with immune perturbations (56). To discriminate the specific impact of SARS-CoV-2 infection on the immune system, we took a broader approach and included hospitalized SARS-CoV-2 ${ }^{\text {neg }}$ patients that are acutely ill and comparable to SARS-CoV $-2^{+}$patients in regards to age and sex and performed a whole blood flow cytometry analysis. We found multiple immune dysregulations in hospitalized patients compared to healthy subjects (Figure 2). Nevertheless, we established specific differences in myeloid (e.g. elevated proportion of ALCAM ${ }^{+}$ monocytes) and lymphocyte (e.g. increased percentage of $\mathrm{CD} 38^{+} \mathrm{CD} 8^{+} \mathrm{T}$ cells) subpopulations in SARS-CoV-2 infected patients compared to SARS-CoV-2 ${ }^{\text {neg }}$ patients (Figure 4A). Finally, a subset of these immune alterations correlated with disease severity and outcome (Figure 3B-C, 4B-C, 5A-B and Table 3). Overall, our study provides the groundwork to develop specific peripheral blood biomarkers to stratify SARS-CoV $-2^{+}$patients at risk of unfavorable outcome and identify novel candidate molecules as potential therapeutic targets.

We observed changes in the proportions of key white blood cell subsets: neutrophils and lymphocytes. Indeed, we detected lymphopenia and neutrophilia in hospitalized patients regardless

of their SARS-CoV-2 status; the most severe perturbations were found in older patients and associated with disease severity as well as disease outcome (Figure 3). Although other groups have 
medRxiv preprint doi: https://doi.org/10.1101/2020.12.21.20248642; this version posted December 22, 2020. The copyright holder for this

linked severe SARS-CoV-2 infection with lymphopenia (57), our results as well as those from others (58) support the notion that lymphopenia is in fact commonly observed in critically ill patients, especially in older patients, and not related to the SARS-CoV-2 infection $(56,59)$. Nevertheless, we found alterations in both innate and adaptive immune cell subpopulations that were specifically associated with SARS-CoV-2 infection.

We observed elevated proportions of pro-inflammatory innate immune cell subsets. Notably, the frequency of $\mathrm{CD} 8^{+}$neutrophils was increased in SARS-CoV $-2^{+}$patients (Figure 4). CD38 expression during neutrophil activation has been shown to play an essential role for appropriate control of pathogen infection and cell migration in affected organs (38). SARS-CoV-2 $2^{+}$patients had a higher proportion of CD $14{ }^{\text {hi }} \mathrm{CD} 16^{+}$monocytes than SARS-CoV-2 ${ }^{\text {neg }}$ patients. This monocyte subset shows robust reactive oxygen species (ROS) and TNF production, strongly promotes proliferation and antigen presentation to $\mathrm{T}$ cells (24). In addition, the frequency of $\mathrm{CD} 1 \mathrm{a}^{+} \mathrm{CD} 14^{+}$ monocytes was higher in SARS-CoV-2 $2^{+}$compared to SARS-CoV-2 ${ }^{\text {neg }}$ patients and such alteration was associated with worse clinical outcome (Figure 4C). CD1 ${ }^{+} \mathrm{CD} 14^{+}$monocytes can activate and induce differentiation of pro-inflammatory IFN $-\gamma^{+} \mathrm{CD}^{+} \mathrm{T}$ cells (60). We found a depletion of $\mathrm{CD}^{+} \mathrm{B}$ cells, which comprise B-1a cells and play a crucial role in innate immunity, in our two groups of hospitalized patients, although this depletion was more pronounced in SARS-CoV-2 ${ }^{+}$ patients and most striking in SARS-CoV-2 $2^{+}$patients with unfavorable outcome (Figure 4C). Such depletion has been described in sepsis (61) and SARS-CoV-2 infection $(55,62) . \mathrm{CD}^{+} \mathrm{B}$ cells can secrete inhibitory cytokines (63) and natural IgM as an early response to pathogen invasion (31), and promote tissue homeostasis and facilitate clearance of apoptotic cells (31). B-1a cells regulate neutrophil lung infiltration, inhibit the production of myeloperoxidase and modulate macrophage responses in ARDS (64). As recently reviewed, further investigations will be necessary to elucidate 
medRxiv preprint doi: https://doi.org/10.1101/2020.12.21.20248642; this version posted December 22, 2020. The copyright holder for this

whether B-1a depletion in SARS-CoV $-2^{+}$patients facilitates aggressive inflammatory response and promotes lung damage (65).

We identified altered expression of cell adhesion molecules on peripheral immune cells from SARS-CoV $-2^{+}$patients and an association of such changes with the outcome, including mortality, among patients with severe COVID-19 (Figure 4, 5B and Table 3). We observed elevated ICAM$1^{+}$on mature and activated neutrophils in SARS-CoV $-2^{+}$patients compared to their SARS-CoV-2 ${ }^{\text {neg }}$ counterparts. Others have suggested that ICAM-1 is acquired by neutrophils as they exit the inflamed tissue to re-enter the circulation (66). This process might contribute to the clearance of neutrophils from the site of injury (67) but can also participate to dissemination of inflammation and promotion of distant organ damage $(42,68)$. Furthermore, ICAM- ${ }^{+}$neutrophils are associated with the formation of neutrophil extracellular traps (NET) $(69,70)$, which is a network of DNA, histone and protein associated with thrombosis. Notably, elevated $\mathrm{ICAM}^{+}$ neutrophil subset was associated with the burden of medical complications (Figure 5A). We further found that ALCAM was present on an elevated proportion of monocytes, and to a lesser extent B cells, in SARS-CoV-2 ${ }^{+}$individuals compared to other groups (Figure 2D and 4A). This elevated proportion of $\mathrm{ALCAM}^{+}$monocytes was associated with severe and fatal COVID-19 and persisted in cases with a bad outcome at 30 days. ALCAM is associated with transmigration of monocytes across pulmonary endothelium (71) and with T cell activation; it could therefore represent a novel relevant therapeutic target in COVID-19.

We detected significant and persistent alterations in the $\mathrm{T}$ cell compartment in SARS-CoV2 ${ }^{+}$ patients compared to other groups. $\mathrm{CD} 38^{+} \mathrm{CD} 8^{+} \mathrm{T}$ cells were more prominent in SARS-CoV-2 $2^{+}$ patients compared to other groups especially in patients who experienced an unfavorable outcome and did not survive. It is possible that $\mathrm{CD} 38^{+} \mathrm{CD} 8^{+} \mathrm{T}$ cells represent overactivated, potentially 
medRxiv preprint doi: https://doi.org/10.1101/2020.12.21.20248642; this version posted December 22, 2020. The copyright holder for this

exhausted and less efficient T cells in viral control, as suggested by HIV studies $(72,73)$. We observed an elevated proportion of T cells carrying PD-1 in both groups of hospitalized patients with higher levels in elderly patients (Figure 2). PD-1 expression on $\mathrm{CD}^{+}$was more pronounced in SARS-CoV $-2^{+}$patients and in patients who required a prolonged stay in the ICU (unfavorable outcome at 30 days). Whereas it is possible that PD-1 upregulation is a physiological attempt to limit immunopathology in the setting of immune hyperactivation and plays a positive role, taken together, our findings raise the question about the therapeutic potential of PD-1/PD-L1 pathway modulation to reverse immune exhaustion in SARS-CoV $-2^{+}$patients, specifically in elderly patients (74-76). Notably, elderly septic patients - particularly those with unfavorable prognosisexhibit a prolonged lymphopenia, a preferential reduction of $\mathrm{CD}^{+} \mathrm{T}$ cells as well as an elevated expression of PD-1 on $\mathrm{CD}^{+}$and $\mathrm{CD}^{+} \mathrm{T}$ cells (77-80). In animal models of sepsis, blockade of the PD-1/PD-L1 pathway restored $\mathrm{T}$ cell function and was associated with a decrease of the pathogen burden and better survival $(76,81-83)$. Whether such approach will be beneficial in the context of COVID-19 will soon be determined by an ongoing phase II trial for treatment of SARSCoV-2 infected patients with an anti-PD-1 monoclonal antibody (ClinicalTrials.gov Identifier: NCT04356508).

From a clinical point of view, the similarities uncovered between the immune dysregulation in SARS-CoV $-2^{+}$and SARS-CoV-2 ${ }^{\text {neg }}$ patients suggest that therapeutics targeting general nonspecific inflammatory processes could be tested in multiple severe acute illness when lymphopenia and neutrophilia are observed, especially in older patients. Some therapies successfully used in sepsis or other ICU care settings could be applied to COVID-19, as exemplified by the use of steroids in severe COVID-19 (84). 
medRxiv preprint doi: https://doi.org/10.1101/2020.12.21.20248642; this version posted December 22, 2020. The copyright holder for this preprint (which was not certified by peer review) is the author/funder, who has granted medRxiv a license to display the preprint in perpetuity. All rights reserved. No reuse allowed without permission.

Our study has identified new biomarkers specifically associated with unfavorable outcome in COVID-19 patients. These surface markers could represent relevant potential therapeutic targets to explore in future studies, in particular PD-1 on $\mathrm{CD}^{+}{ }^{+} \mathrm{T}$ cells, and ICAM-1 and ALCAM on neutrophils and antigen presenting cells (B cells, monocytes). Finally, our longitudinal investigation has revealed markers that could predict worse outcome and correlate with medical complications and mortality (Figure 5A and Table 3). We believe our experimental approach, whole blood staining and flow cytometry analysis, could be easily used in hospital diagnostic biochemistry laboratories to follow patients overtime and could complement other clinical follow-ups. 
medRxiv preprint doi: https://doi.org/10.1101/2020.12.21.20248642; this version posted December 22, 2020. The copyright holder for this

\section{Methods}

\section{Cohort}

Fifty SARS-CoV-2 positive patients and twenty-two SARS-CoV-2 negative patients admitted to the University of Montreal hospital center (CHUM) between April $7^{\text {th }}$ and May $7^{\text {th }} 2020$, as well as 49 healthy controls from the CHUM personnel, were prospectively recruited to the study and included in the Biobanque Québécoise de la COVID-19 (BQC19). None of the patients included received an experimental treatment for COVID-19 (e.g. hydroxychloroquine, remdesevir, antiIL-6) prior to peripheral blood sampling. One SARS-CoV $-2^{+}$patient had to be excluded from analysis related to outcome and survival for participation after baseline sampling in an experimental pharmacological assay. SARS-CoV $-2^{+}$and SARS-CoV $-2^{\text {neg }}$ status was determined by PCR (repeated once when negative) among hospitalized patients. The absence of IgM or IgG antibodies against SARS-CoV-2 in the serum of SARS-CoV-2 ${ }^{\text {neg }}$ hospitalized patients and of healthy controls was used to confirm the status of the donors. When possible follow-up samples were obtained at $24 \mathrm{~h}-72 \mathrm{~h}(\mathrm{t} 1)$ and at 4-8 days (t2) after the baseline sample (t0) for SARS-CoV$2^{+}$patients. A follow-up sample at $24-72 \mathrm{~h}$ was obtained from 32 SARS-CoV-2 ${ }^{+}$subjects, at 4-7 days from 28 subjects and at both timepoints for 21 subjects. For some subanalyses, patients were stratified according to age: younger $<60$ y.o. vs. older $\geq 60$ y.o. Hospitalization in the ICU was used to define other severe acute illness in SARS-CoV-2 ${ }^{\text {neg }}$ patients, and the need for high-flow or invasive ventilation in SARS-CoV-2 ${ }^{+}$patients to define severe COVID-19. In our cohort 14/22 patients were classified as other severe acute illness and 21/50 as severe COVID-19. The 8-point NIH Ordinal Severity scale (ranging from $1=$ death to $8=$ discharged at home with no required care) was used to describe the outcome at 30 days. A score of 1-4 on the NIH scale was used to define an unfavorable or bad outcome, while a score of 5 to 8 was used to define a favorable or 
medRxiv preprint doi: https://doi.org/10.1101/2020.12.21.20248642; this version posted December 22, 2020. The copyright holder for this

good outcome at 30 days. Mortality up to 60 days after sampling was considered when indicated.

Medical charts were reviewed by two independent physicians to collect clinical information.

\section{Flow cytometry}

Blood was obtained through venous puncture and collected in tubes containing trisodium citrate, citric acid and dextrose (ACD) tubes. 150 ul whole blood was used for each staining (3 stainings/sample). Red blood cells were lysed using a 15min incubation with BD PharmLyse solution (\#555899) at room temperature according to the manufacturer's instructions. After subsequent washing, samples were blocked for $15 \mathrm{~min}$ with $50 \mathrm{uL}$ of mouse $\operatorname{IgG}$ (Invitrogen \#10400C) diluted 1:10. Three antibody panels were used, details of which are summarized in Supplemental Tables 2-4. BD Brilliant Buffer (\#566349) was added to all antibody cocktails to minimize staining artifacts. Following 20 minutes incubation at $4{ }^{\circ} \mathrm{C}$, cells were washed and fixed with BD Cytofix solution (\#554655) for 20 minutes. Samples were acquired on a BD FACSFortessa. BD FACSDiva ${ }^{\mathrm{TM}}$ CS\&T research beads (\#655051) were acquired biweekly to ensure the stability of the cytometer. SPHERO supra rainbow fluorescent particles (Spherotech \#SRCP-35-2A) were recorded prior to sample acquisition to assess laser instabilities. Onecomp eBeads (Invitrogen \#01-1111-42) and UltraComp eBeads (Invitrogen \#01-3333-42) were used for compensation and manual correction for each antibody panel was performed before analysis and applied to all samples.

Flow cytometry analysis

Flow cytometric data analysis was performed using FlowJo (version 10.6.2). For both biased and unbiased analysis, doublets were excluded, and events were pre-gated on the FSC-A vs. SSC-A biplot to define granulocytic, monocytic and lymphocytic cell lineages based on size and granularity. Compensation matrices were calculated and applied. Data-driven analysis was 
medRxiv preprint doi: https://doi.org/10.1101/2020.12.21.20248642; this version posted December 22, 2020. The copyright holder for this

performed on select cell lineages, depending on the antibodies included in each panel: analysis of the first panel was performed on the events within the monocytic gate and the granulocytic gate, analysis of the second panel on the events within the monocytic gate and the lymphocytic gate, and analysis of the third panel on the events within the lymphocytic gate. Samples were then downsampled to an equal size and one large concatenated file was generated for each panel. Using the R packages flowCore 2.0.1 and FlowSOM 1.20.0 in R version 4.0.1, we applied the FlowSOM algorithm(20) on these concatenated files to create a FlowSOM map for each panel. The modal value of clusters, as determined by the PhenoGraph clustering algorithm(19) in FlowJo on multiple random samples, was used to determine the number of clusters to input into FlowSOM. A heatmap of each panel's geometric mean fluorescence intensity (MFI) for each cellular cluster was generated with the $\mathrm{R}$ package pheatmap 1.0.12. UMAPs were generated using the $\mathrm{R}$ package UMAP 0.2.6.0.

\section{Statistics}

Analysis of frequency of populations and their association with SARS-CoV-2 status, severity and outcome at 30 days were performed by Mann-Whitney U test (for factors with 2 categories) or by Kruskal-Wallis test (for factors with a number of categories $>2$ ) followed by Dunn's post-hoc test. All tests were performed two-sided, using a nominal significance threshold of $\mathrm{p}<0.05$. For identification of populations of interest (Figure 2A and 2D), nominal p-values for Kruskal-Wallis tests were adjusted for Multiple testing (adjusted $\mathrm{p}$ value) within each stain separately using the method of Benjamin and Hochberg (85), which controls the false discovery rate at a significance threshold we set at 0.05 . Association between clinical categorical variables was assessed by fisher exact test. Correlation between continuous features were quantified by the Spearman rank correlation. To assess frequency of specific immune cell populations over time, longitudinal 
medRxiv preprint doi: https://doi.org/10.1101/2020.12.21.20248642; this version posted December 22, 2020. The copyright holder for this

analysis was performed using generalized estimation equation as implemented in the $\mathrm{R}$ package gee using exchangeable correlation structure and including time as the fixed effect variable and patient ID as the random variable.

Multivariate prediction of the SARS-CoV-2 $2^{+}$, SARS-CoV $-2^{\text {neg }}$ and $\mathrm{HC}$ status, using as candidate predictor variables the whole set of the immune subpopulations, was performed using a random forest (52) classification models as implemented in the randomForest 4.6-14 R package using 1000 random trees and the default "mtry" (number of variables randomly sampled and tested in each node) parameter. A misclassification error for each status was calculated as the out-of-bag error by testing on the samples which were not randomly drawn at each tree generation. All statistical analyses were performed using the statistical package $\mathrm{R}$ version 4.0.1.

\section{Study approval}

This study was approved by the CRCHUM ethic committee in accordance with the Declaration of Helsinki (IRB protocols 19.387 and 19.389). Informed consent was obtained for each patient and is detailed elsewhere(86).

\section{Author contributions}

C.L., A.P., D.E.K., N.A., R.M.R, M.Charabati and C.G. designed the study and wrote the manuscript; the order of co-first authors was determined by flipping a coin; C.L., A.P., D.E.K., and N.A. supervised the study; A.F, J.F.C and N.C. provided scientific input for designing the study and writing the manuscript; R.B., Y.C.S., N.F., A.P.F., E.G., H.J., F.L., V.A.M., A.C.M, N.B., A.D., L.B. and K.T. performed experiments; C.L., A.F.M., O.T., R.M.R, M.Charabati and C.G. performed analysis; M.Chassé and M.D. recruited patients for the study. 


\section{Acknowledgments}

\section{Funding}

This study was funded by a grant from the CRCHUM foundation and by grant VR2-173203 from the Canada's COVID-19 Immunity Task Force (CITF), in collaboration with the Canadian Institutes of Health Research (CIHR). The Biobanque Québécoise de la COVID-19 (BQC-19) is supported by the Fonds de recherche Québec-Santé (FRQS), Génome Québec and the Public Health Agency of Canada. D.E.K is a FRQS Merit Research Scholar. N.C., M.D. and C.L. receive a salary award from the FRQS. A.Finzi. and A.P. hold a Canada Research Chair.

We gratefully acknowledge Dominique Gauchat and Philippe St-Onge from the flow cytometry platform from CRCHUM for excellent technical guidance and support.

Conflicts of interest: The authors declare no conflict of interest. 
medRxiv preprint doi: https://doi.org/10.1101/2020.12.21.20248642; this version posted December 22, 2020. The copyright holder for this preprint (which was not certified by peer review) is the author/funder, who has granted medRxiv a license to display the preprint in perpetuity. All rights reserved. No reuse allowed without permission.

\section{References}

1. Guan W-j, Ni Z-y, Hu Y, Liang W-h, Ou C-q, He J-x, et al. Clinical characteristics of coronavirus disease 2019 in China. New England journal of medicine. 2020;382(18):170820.

2. Richardson S, Hirsch JS, Narasimhan M, Crawford JM, McGinn T, Davidson KW, et al. Presenting Characteristics, Comorbidities, and Outcomes Among 5700 Patients Hospitalized With COVID-19 in the New York City Area. JAMA. 2020;323(20):2052-9.

3. Petrilli CM, Jones SA, Yang J, Rajagopalan H, O’Donnell L, Chernyak Y, et al. Factors associated with hospital admission and critical illness among 5279 people with coronavirus disease 2019 in New York City: prospective cohort study. BMJ. 2020;369:m1966.

4. Williamson EJ, Walker AJ, Bhaskaran K, Bacon S, Bates C, Morton CE, et al. Factors associated with COVID-19-related death using OpenSAFELY. Nature. 2020;584(7821):4306.

5. Onder G, Rezza G, and Brusaferro S. Case-Fatality Rate and Characteristics of Patients Dying in Relation to COVID-19 in Italy. JAMA. 2020;323(18):1775-6.

6. Wu Z, and McGoogan JM. Characteristics of and Important Lessons From the Coronavirus Disease 2019 (COVID-19) Outbreak in China: Summary of a Report of 72314 Cases From the Chinese Center for Disease Control and Prevention. JAMA. 2020;323(13):1239-42.

7. Zhang B, Zhou X, Qiu Y, Song Y, Feng F, Feng J, et al. Clinical characteristics of 82 cases of death from COVID-19. PLOS ONE. 2020;15(7):e0235458.

8. Franceschi C, Garagnani P, Parini P, Giuliani C, and Santoro A. Inflammaging: a new immune-metabolic viewpoint for age-related diseases. Nat Rev Endocrinol. 2018;14(10):576-90.

9. Aguilar EG, and Murphy WJ. Obesity induced T cell dysfunction and implications for cancer immunotherapy. Curr Opin Immunol. 2018;51:181-6.

10. Bantug GR, Galluzzi L, Kroemer G, and Hess C. The spectrum of T cell metabolism in health and disease. Nat Rev Immunol. 2018;18(1):19-34.

11. Honce R, and Schultz-Cherry S. Impact of Obesity on Influenza A Virus Pathogenesis, Immune Response, and Evolution. Front Immunol. 2019;10:1071.

12. Keilich SR, Bartley JM, and Haynes L. Diminished immune responses with aging predispose older adults to common and uncommon influenza complications. Cell Immunol. 2019;345:103992.

13. Rowe TA, and McKoy JM. Sepsis in Older Adults. Infect Dis Clin North Am. 2017;31(4):73142.

14. Mathew D, Giles JR, Baxter AE, Oldridge DA, Greenplate AR, Wu JE, et al. Deep immune profiling of COVID-19 patients reveals distinct immunotypes with therapeutic implications. Science. 2020;369(6508):eabc8511.

15. Kuri-Cervantes L, Pampena MB, Meng W, Rosenfeld AM, Ittner CAG, Weisman AR, et al. Comprehensive mapping of immune perturbations associated with severe COVID-19. Science Immunology. 2020;5(49):eabd7114. 
medRxiv preprint doi: https://doi.org/10.1101/2020.12.21.20248642; this version posted December 22, 2020. The copyright holder for this preprint (which was not certified by peer review) is the author/funder, who has granted medRxiv a license to display the preprint in perpetuity. All rights reserved. No reuse allowed without permission.

16. Diao B, Wang C, Tan Y, Chen X, Liu Y, Ning L, et al. Reduction and Functional Exhaustion of T Cells in Patients With Coronavirus Disease 2019 (COVID-19). Frontiers in Immunology. 2020;11(827).

17. Pan F, Yang L, Li Y, Liang B, Li L, Ye T, et al. Factors associated with death outcome in patients with severe coronavirus disease-19 (COVID-19): a case-control study. Int J Med Sci. 2020;17(9):1281-92.

18. Helms J, Kremer S, Merdji H, Clere-Jehl R, Schenck M, Kummerlen C, et al. Neurologic Features in Severe SARS-CoV-2 Infection. N Engl J Med. 2020;382(23):2268-70.

19. Levine JH, Simonds EF, Bendall SC, Davis KL, Amir el AD, Tadmor MD, et al. Data-Driven Phenotypic Dissection of AML Reveals Progenitor-like Cells that Correlate with Prognosis. Cell. 2015;162(1):184-97.

20. Van Gassen S, Callebaut B, Van Helden MJ, Lambrecht BN, Demeester P, Dhaene T, et al. FlowSOM: Using self-organizing maps for visualization and interpretation of cytometry data. Cytometry A. 2015;87(7):636-45.

21. Zhou R, To KK-W, Wong Y-C, Liu L, Zhou B, Li X, et al. Acute SARS-CoV-2 Infection Impairs Dendritic Cell and T Cell Responses. Immunity. 2020;53(4):864-77.e5.

22. Leijte GP, Rimmelé T, Kox M, Bruse N, Monard C, Gossez M, et al. Monocytic HLA-DR expression kinetics in septic shock patients with different pathogens, sites of infection and adverse outcomes. Crit Care. 2020;24(1):110.

23. Remy KE, Mazer M, Striker DA, Ellebedy AH, Walton AH, Unsinger J, et al. Severe immunosuppression and not a cytokine storm characterizes COVID-19 infections. $\mathrm{JCI}$ Insight. 2020;5(17).

24. Ziegler-Heitbrock L. The CD14+ CD16+ blood monocytes: their role in infection and inflammation. Journal of Leukocyte Biology. 2007;81(3):584-92.

25. Liu E, Tu W, Law HKW, and Lau Y-L. Changes of CD14 and CD1a Expression in Response to IL-4 and Granulocyte-Macrophage Colony-Stimulating Factor Are Different in Cord Blood and Adult Blood Monocytes. Pediatric Research. 2001;50(2):184-9.

26. Sormani MP. An Italian programme for COVID-19 infection in multiple sclerosis. The Lancet Neurology. 2020;19(6):481-2.

27. Ju B, Zhang Q, Ge J, Wang R, Sun J, Ge X, et al. Human neutralizing antibodies elicited by SARS-CoV-2 infection. Nature. 2020;584(7819):115-9.

28. Liu L, Wang P, Nair MS, Yu J, Rapp M, Wang Q, et al. Potent neutralizing antibodies against multiple epitopes on SARS-CoV-2 spike. Nature. 2020;584(7821):450-6.

29. Gaebler C, Wang Z, Lorenzi JCC, Muecksch F, Finkin S, Tokuyama M, et al. Evolution of Antibody Immunity to SARS-CoV-2. bioRxiv. 2020:2020.11.03.367391.

30. Prévost J, Gasser R, Beaudoin-Bussières G, Richard J, Duerr R, Laumaea A, et al. CrossSectional Evaluation of Humoral Responses against SARS-CoV-2 Spike. Cell Rep Med. 2020;1(7):100126-.

31. Morris G, Puri BK, Olive L, Carvalho AF, Berk M, and Maes M. Emerging role of innate B1 cells in the pathophysiology of autoimmune and neuroimmune diseases: Association with inflammation, oxidative and nitrosative stress and autoimmune responses. Pharmacol Res. 2019;148:104408.

32. Soldevila G, Raman C, and Lozano F. The immunomodulatory properties of the CD5 lymphocyte receptor in health and disease. Curr Opin Immunol. 2011;23(3):310-8. 
medRxiv preprint doi: https://doi.org/10.1101/2020.12.21.20248642; this version posted December 22, 2020. The copyright holder for this preprint (which was not certified by peer review) is the author/funder, who has granted medRxiv a license to display the preprint in perpetuity. All rights reserved. No reuse allowed without permission.

33. Gary-Gouy H, Harriague J, Bismuth G, Platzer C, Schmitt C, and Dalloul AH. Human CD5 promotes B-cell survival through stimulation of autocrine IL-10 production. Blood. 2002;100(13):4537-43.

34. Rojas OL, Narváez CF, Greenberg HB, Angel J, and Franco MA. Characterization of rotavirus specific $\mathrm{B}$ cells and their relation with serological memory. Virology. 2008;380(2):234-42.

35. Colonna-Romano G, Bulati M, Aquino A, Pellicanò M, Vitello S, Lio D, et al. A doublenegative (IgD-CD27-) B cell population is increased in the peripheral blood of elderly people. Mech Ageing Dev. 2009;130(10):681-90.

36. Wei C, Anolik J, Cappione A, Zheng B, Pugh-Bernard A, Brooks J, et al. A new population of cells lacking expression of CD27 represents a notable component of the B cell memory compartment in systemic lupus erythematosus. J Immunol. 2007;178(10):6624-33.

37. Moir S, Ho J, Malaspina A, Wang W, DiPoto AC, O'Shea MA, et al. Evidence for HIVassociated $B$ cell exhaustion in a dysfunctional memory B cell compartment in HIVinfected viremic individuals. J Exp Med. 2008;205(8):1797-805.

38. Glaría E, and Valledor AF. Roles of CD38 in the Immune Response to Infection. Cells. 2020;9(1).

39. Jubel JM, Barbati ZR, Burger C, Wirtz DC, and Schildberg FA. The Role of PD-1 in Acute and Chronic Infection. Front Immunol. 2020;11:487.

40. Filep JG, and Ariel A. Neutrophil heterogeneity and fate in inflamed tissues: implications for the resolution of inflammation. American Journal of Physiology-Cell Physiology. 2020;319(3):C510-C32.

41. Nourshargh S, and Alon R. Leukocyte Migration into Inflamed Tissues. Immunity. 2014;41(5):694-707.

42. Woodfin A, Beyrau M, Voisin MB, Ma B, Whiteford JR, Hordijk PL, et al. ICAM-1-expressing neutrophils exhibit enhanced effector functions in murine models of endotoxemia. Blood. 2016;127(7):898-907.

43. Filippi M-D. Neutrophil transendothelial migration: updates and new perspectives. Blood. 2019;133(20):2149-58.

44. Wang JH, Sexton DM, Redmond HP, Watson RW, Croke DT, and Bouchier-Hayes D. Intercellular adhesion molecule-1 (ICAM-1) is expressed on human neutrophils and is essential for neutrophil adherence and aggregation. Shock. 1997;8(5):357-61.

45. Takashi S, Okubo Y, and Horie S. Contribution of CD54 to human eosinophil and neutrophil superoxide production. J Appl Physiol (1985). 2001;91(2):613-22.

46. Zimmerman AW, Joosten B, Torensma R, Parnes JR, van Leeuwen FN, and Figdor CG. Longterm engagement of CD6 and ALCAM is essential for T-cell proliferation induced by dendritic cells. Blood. 2006;107(8):3212-20.

47. Golinski M-L, Demeules M, Derambure C, Riou G, Maho-Vaillant M, Boyer O, et al. CD11C+ $B$ Cells Are Mainly Memory Cells, Precursors of Antibody Secreting Cells in Healthy Donors. Frontiers in Immunology. 2020;11(32).

48. Maus UA, Wellmann S, Hampl C, Kuziel WA, Srivastava M, Mack M, et al. CCR2-positive monocytes recruited to inflamed lungs downregulate local CCL2 chemokine levels. Am J Physiol Lung Cell Mol Physiol. 2005;288(2):L350-8. 
medRxiv preprint doi: https://doi.org/10.1101/2020.12.21.20248642; this version posted December 22, 2020. The copyright holder for this preprint (which was not certified by peer review) is the author/funder, who has granted medRxiv a license to display the preprint in perpetuity. All rights reserved. No reuse allowed without permission.

49. Merad M, and Martin JC. Pathological inflammation in patients with COVID-19: a key role for monocytes and macrophages. Nature Reviews Immunology. 2020;20(6):355-62.

50. Beyer M, Wang H, Peters N, Doths S, Koerner-Rettberg C, Openshaw PJ, et al. The beta2 integrin $\mathrm{CD} 11 \mathrm{c}$ distinguishes a subset of cytotoxic pulmonary $\mathrm{T}$ cells with potent antiviral effects in vitro and in vivo. Respir Res. 2005;6(1):70.

51. Vinay DS, Kim CH, Choi BK, and Kwon BS. Origins and functional basis of regulatory CD11c+CD8+ T cells. Eur J Immunol. 2009;39(6):1552-63.

52. Breiman L. Random forests. Machine learning. 2001;45(1):5-32.

53. Liang $\mathrm{K}-\mathrm{Y}$, and Zeger SL. Longitudinal data analysis using generalized linear models. Biometrika. 1986;73(1):13-22.

54. Wang F, Nie J, Wang H, Zhao Q, Xiong Y, Deng L, et al. Characteristics of Peripheral Lymphocyte Subset Alteration in COVID-19 Pneumonia. J Infect Dis. 2020;221(11):17629.

55. Laing AG, Lorenc A, del Molino del Barrio I, Das A, Fish M, Monin L, et al. A dynamic COVID19 immune signature includes associations with poor prognosis. Nature Medicine. 2020;26(10):1623-35.

56. Duggal NA, Snelson C, Shaheen U, Pearce V, and Lord JM. Innate and adaptive immune dysregulation in critically ill ICU patients. Sci Rep. 2018;8(1):10186-.

57. Sokolowska M, Lukasik Z, Agache I, Akdis C, Akdis D, Akdis M, et al. Immunology of COVID19: mechanisms, clinical outcome, diagnostics and perspectives - a report of the European Academy of Allergy and Clinical Immunology (EAACI). Allergy. 2020;n/a(n/a).

58. Stefania V, Dalila M, Barbara O, Stefania M, Serena L, Antonella C, et al. Unique Immunological Profile In Patients With COVID-19. Research Square. 2020.

59. Zahorec R. Ratio of neutrophil to lymphocyte counts--rapid and simple parameter of systemic inflammation and stress in critically ill. Bratis/ Lek Listy. 2001;102(1):5-14.

60. Al-Amodi O, Jodeleit H, Beigel F, Wolf E, Siebeck M, and Gropp R. CD1a-Expressing Monocytes as Mediators of Inflammation in Ulcerative Colitis. Inflamm Bowel Dis. 2018;24(6):1225-36.

61. Monserrat J, de Pablo R, Diaz-Martín D, Rodríguez-Zapata M, de la Hera A, Prieto A, et al. Early alterations of B cells in patients with septic shock. Crit Care. 2013;17(3):R105-R.

62. Wen $W$, Su W, Tang $H$, Le $W$, Zhang $X$, Zheng $Y$, et al. Immune cell profiling of COVID-19 patients in the recovery stage by single-cell sequencing. Cell Discov. 2020;6:31.

63. Aziz M, Holodick NE, Rothstein TL, and Wang P. B-1a Cells Protect Mice from Sepsis: Critical Role of CREB. The Journal of Immunology. 2017;199(2):750.

64. Aziz M, Ode Y, Zhou M, Ochani M, Holodick NE, Rothstein TL, et al. B-1a cells protect mice from sepsis-induced acute lung injury. Molecular Medicine. 2018;24(1):26.

65. Aziz M, Brenner M, and Wang P. Therapeutic Potential of B-1a Cells in COVID-19. Shock. 2020;54(5):586-94.

66. Buckley CD, Ross EA, McGettrick HM, Osborne CE, Haworth O, Schmutz C, et al. Identification of a phenotypically and functionally distinct population of long-lived neutrophils in a model of reverse endothelial migration. Journal of Leukocyte Biology. 2006;79(2):303-11. 
medRxiv preprint doi: https://doi.org/10.1101/2020.12.21.20248642; this version posted December 22, 2020. The copyright holder for this preprint (which was not certified by peer review) is the author/funder, who has granted medRxiv a license to display the preprint in perpetuity. All rights reserved. No reuse allowed without permission.

67. Mathias JR, Perrin BJ, Liu TX, Kanki J, Look AT, and Huttenlocher A. Resolution of inflammation by retrograde chemotaxis of neutrophils in transgenic zebrafish. J Leukoc Biol. 2006;80(6):1281-8.

68. Colom B, Bodkin Jennifer V, Beyrau M, Woodfin A, Ody C, Rourke C, et al. Leukotriene B4Neutrophil Elastase Axis Drives Neutrophil Reverse Transendothelial Cell Migration In Vivo. Immunity. 2015;42(6):1075-86.

69. Folco EJ, Mawson TL, Vromman A, Bernardes-Souza B, Franck G, Persson O, et al. Neutrophil Extracellular Traps Induce Endothelial Cell Activation and Tissue Factor Production Through Interleukin-1 $\alpha$ and Cathepsin G. Arterioscler Thromb Vasc Biol. 2018;38(8):1901-12.

70. Ode Y, Aziz M, and Wang P. CIRP increases ICAM-1+ phenotype of neutrophils exhibiting elevated iNOS and NETs in sepsis. Journal of leukocyte biology. 2018;103(4):693-707.

71. Masedunskas A, King JA, Tan F, Cochran R, Stevens T, Sviridov D, et al. Activated leukocyte cell adhesion molecule is a component of the endothelial junction involved in transendothelial monocyte migration. FEBS Letters. 2006;580(11):2637-45.

72. Hua S, Lécuroux C, Sáez-Cirión A, Pancino G, Girault I, Versmisse P, et al. Potential role for HIV-specific CD38-/HLA-DR+ CD8+ T cells in viral suppression and cytotoxicity in HIV controllers. PLoS One. 2014;9(7):e101920.

73. Taborda NA, González SM, Alvarez CM, Correa LA, Montoya CJ, and Rugeles MT. Higher Frequency of NK and CD4+ T-Cells in Mucosa and Potent Cytotoxic Response in HIV Controllers. PLoS One. 2015;10(8):e0136292.

74. Saeidi A, Zandi K, Cheok YY, Saeidi H, Wong WF, Lee CYQ, et al. T-Cell Exhaustion in Chronic Infections: Reversing the State of Exhaustion and Reinvigorating Optimal Protective Immune Responses. Frontiers in Immunology. 2018;9(2569).

75. Chang K, Svabek C, Vazquez-Guillamet C, Sato B, Rasche D, Wilson S, et al. Targeting the programmed cell death 1: programmed cell death ligand 1 pathway reverses $\mathrm{T}$ cell exhaustion in patients with sepsis. Critical care. 2014;18(1):R3.

76. Brahmamdam P, Inoue S, Unsinger J, Chang KC, McDunn JE, and Hotchkiss RS. Delayed administration of anti-PD-1 antibody reverses immune dysfunction and improves survival during sepsis. Journal of leukocyte biology. 2010;88(2):233-40.

77. Inoue S, Suzuki-Utsunomiya K, Okada Y, Taira T, lida Y, Miura N, et al. Reduction of immunocompetent $T$ cells followed by prolonged lymphopenia in severe sepsis in the elderly. Crit Care Med. 2013;41(3):810-9.

78. Guignant C, Lepape A, Huang X, Kherouf H, Denis L, Poitevin F, et al. Programmed death1 levels correlate with increased mortality, nosocomial infection and immune dysfunctions in septic shock patients. Crit Care. 2011;15(2):R99.

79. Zhang Y, Li J, Lou J, Zhou Y, Bo L, Zhu J, et al. Upregulation of programmed death-1 on T cells and programmed death ligand-1 on monocytes in septic shock patients. Crit Care. 2011;15(1):R70.

80. Patera AC, Drewry AM, Chang K, Beiter ER, Osborne D, and Hotchkiss RS. Frontline Science: Defects in immune function in patients with sepsis are associated with PD-1 or PD-L1 expression and can be restored by antibodies targeting PD-1 or PD-L1. J Leukoc Biol. 2016;100(6):1239-54. 
medRxiv preprint doi: https://doi.org/10.1101/2020.12.21.20248642; this version posted December 22, 2020. The copyright holder for this preprint (which was not certified by peer review) is the author/funder, who has granted medRxiv a license to display the preprint in perpetuity. All rights reserved. No reuse allowed without permission.

81. Zhang Y, Zhou Y, Lou J, Li J, Bo L, Zhu K, et al. PD-L1 blockade improves survival in experimental sepsis by inhibiting lymphocyte apoptosis and reversing monocyte dysfunction. Critical Care. 2010;14(6):R220.

82. Busch LM, Sun J, Cui X, Eichacker PQ, and Torabi-Parizi P. Checkpoint inhibitor therapy in preclinical sepsis models: a systematic review and meta-analysis. Intensive Care Medicine Experimental. 2020;8(1):7.

83. Chang KC, Burnham CA, Compton SM, Rasche DP, Mazuski RJ, McDonough JS, et al. Blockade of the negative co-stimulatory molecules PD-1 and CTLA-4 improves survival in primary and secondary fungal sepsis. Crit Care. 2013;17(3):R85.

84. Prescott HC, and Rice TW. Corticosteroids in COVID-19 ARDS: Evidence and Hope During the Pandemic. JAMA. 2020;324(13):1292-5.

85. Benjamini $Y$, and Hochberg Y. Controlling the False Discovery Rate: A Practical and Powerful Approach to Multiple Testing. Journal of the Royal Statistical Society Series B (Methodological). 1995;57(1):289-300.

86. Knoppers BM, Beauvais MJS, Joly Y, Zawati MH, Rousseau S, Chassé M, et al. Modeling consent in the time of COVID-19. Journal of Law and the Biosciences. 2020;7(1). 
medRxiv preprint doi: https://doi.org/10.1101/2020.12.21.20248642; this version posted December 22, 2020. The copyright holder for this

\section{Figure legends}

\section{Figure 1. Clinical characteristics and data-driven flow cytometry analysis.}

(A) Association among clinical parameters in hospitalized patients as illustrated by heatmap and hierarchical clustering of the $-\log 10(P$-value $)$. Fisher exact test for association of binary variables (upper part), and Wilcoxon rank sum test for association between binary and continuous variables (lower part). Blue squares indicate that only SARS-CoV $-2^{+}$patients were considered for this parameter. (B) Representative dot plots of multiple samples acquired in four different batches for CD19-BV605, CD4-BUV496, IgD-PE-Cy7 and CD24-PerCP-Cy5.5. Red arrows identify samples from the same individual acquired in two different batches. (C-D-E) Representation of FlowSOM populations on UMAP projection axis and their corresponding heatmap showing geometric mean fluorescence of the different markers for the different subpopulations (unbiased analysis). Cellular markers are indicated on the $\mathrm{x}$-axis and population number on the $\mathrm{y}$-axis of heatmaps.

Figure 2. Common and distinct alterations in immune cell populations in SARS-CoV-2 ${ }^{+}$and SARS-CoV-2 ${ }^{\text {neg }}$ hospitalized patients.

(A-C) Data-driven analysis. (A) Heatmap showing the median frequencies of immune cell populations differentially regulated in SARS-CoV $-2^{+}$patients $\left(\mathrm{CoV}-2^{+}\right), \mathrm{SARS}-\mathrm{CoV}-2^{\text {neg }}(\mathrm{CoV}-$ $2^{\text {neg }}$ ) and healthy control (HC) samples. (B-C) Box and Whisker plots showing frequencies of dysregulated immune cell populations in (B) $\mathrm{CoV}_{-} 2^{+}$(red) compared to $\mathrm{CoV}-2^{\text {neg }}$ (yellow) and $\mathrm{HC}$ (blue) and in (C) hospitalized patients (both $\mathrm{CoV}-2^{+}$and $\mathrm{CoV}-2^{\text {neg }}$ ) compared to $\mathrm{HC}$ (blue). HC, $n$ $=49 ; \mathrm{CoV}-2^{\text {neg }}, n=21 ; \mathrm{CoV}-2^{+}, n=42$. Kruskal-Wallis test followed by a Dunn's post hoc-test for multiple pairwise comparisons. ${ }^{*} P<0.05$; $* * P<0.01$; $* * * * P<0.0001$. (D) Hypothesis-driven (conventional) analysis. Heatmaps showing the median frequency of immune cell populations 
medRxiv preprint doi: https://doi.org/10.1101/2020.12.21.20248642; this version posted December 22, 2020. The copyright holder for this

identified as significantly altered (adjusted $P<0.05)$ in $\mathrm{CoV}-2^{+}(n=50)$ compared to $\mathrm{HC}(n=49)$ and/or CoV-2 ${ }^{\text {neg }}(n=22)$ in stain 1 (S1 panel), stain 2 (S2 panel) and (stain 3 (S3 panel). KruskalWallis test followed by a Dunn's post hoc-test for multiple pairwise comparisons. Nominal $P$ values were adjusted for multiple testing within each stain, false discovery rate significance threshold set at 0.05 . Color scale legends the z-score, across the groups, of sub-population median frequencies. Populations significantly altered $(P<0.05)$ in SARS-CoV-2 ${ }^{+}$compared to HC and to SARS-CoV-2 ${ }^{\text {neg }}$ samples are in bold.

Figure 3. Alterations in immune cell populations commonly observed in SARS-CoV-2 ${ }^{+}$and SARS-CoV-2 ${ }^{\text {neg }}$ hospitalized patients. (A-C) Frequencies of different subsets of immune cell populations in peripheral blood (conventional analysis) from SARS-CoV-2 ${ }^{+}\left(\mathrm{CoV}-2^{+}\right.$, red) and SARS-CoV-2 ${ }^{\text {neg }}\left(\mathrm{CoV}-2^{\text {neg }}\right.$, yellow) hospitalized patients and healthy controls (HC, blue) (A) according to age group ( $\mathrm{HC}<60$ y.o. $\mathrm{n}=49$; $\mathrm{CoV}-2^{\text {neg }}$ hospitalized $<60$ y.o. $n=9$; $\geq 60$ y.o. $n=$ 13; CoV-2 ${ }^{+}:<60$ y.o. $n=20 ; \geq 60$ y.o. $\mathrm{n}=30$ ), (B) according to disease severity in hospitalized patients $\left(\mathrm{CoV}-2^{\text {neg }}\right.$ mild/moderate disease $n=8$, severe disease $n=14 ; \mathrm{CoV}-2^{+} \mathrm{mild} / \mathrm{moderate}$ disease $n=29$, severe disease $n=21$, and (C) according to clinical outcome at 30 days in SARS$\mathrm{CoV}-2^{+}$patients (NIH score $5-8, n=36$ ) vs. (NIH score $1-4, n=14$ ). Mann-Whitney $U$ test (for $n$ $=2$ categories) and Kruskal-Wallis test (for $n>2$ categories) followed by Dunn's post-hoc test for the multiple pairwise comparisons were used. Each dot represents one donor. $* P<0.05$; $* * P<$ $0.01 ; * * * P<0.001 ; * * * * P<0.0001$.

Figure 4. Alterations in immune cell populations distinguishing SARS-CoV-2 ${ }^{+}$from SARSCoV-2 ${ }^{\text {neg }}$ hospitalized patients. (A-C) Frequencies of different subsets of immune cell 
medRxiv preprint doi: https://doi.org/10.1101/2020.12.21.20248642; this version posted December 22, 2020. The copyright holder for this

populations in peripheral blood (conventional analysis) from SARS-CoV-2 ${ }^{+}\left(\mathrm{CoV}-2^{+}\right.$, red) and SARS-CoV-2 ${ }^{\text {neg }}\left(\mathrm{CoV}-2^{\text {neg }}\right.$, yellow) hospitalized patients and healthy controls (HC, blue) (A) according to age groups ( $\mathrm{HC}<60$ y.o. $n=49$; CoV- $2^{\text {neg }}$ hospitalized $<60$ y.o. $n=9$, $\geq 60$ y.o. $n=$ 13; CoV-2 ${ }^{+}:<60$ y.o. $n=20, \geq 60$ y.o. $n=30$ ), (B) according to disease severity in hospitalized patients $\left(\mathrm{CoV}-2^{\text {neg }}\right.$ mild/moderate disease $n=8$, severe disease $n=14 ; \mathrm{CoV}-2^{+}$mild $/$moderate disease $n=29$, severe disease $n=21$, and (C) according to clinical outcome at 30 days in SARS$\mathrm{CoV}-2^{+}$patients (NIH score $5-8, n=36$ ) vs. (NIH score $1-4, n=14$ ). Mann-Whitney $U$ test (for $n$ $=2$ categories) and Kruskal-Wallis test (for $n>2$ categories) followed by Dunn's post-hoc test for the multiple pairwise comparisons were used. Each dot represents one donor. ${ }^{*} P<0.05$; $* * P<$ $0.01 ; * * * P<0.001 ; * * * * P<0.0001$.

Figure 5. Association between clinical parameters and longitudinal analysis of immune cell populations altered in SARS-CoV-2 ${ }^{+}$patients. (A) Association between immune cell subsets and clinical parameters in SARS-CoV-2 ${ }^{+}$patients as illustrated by heatmap and hierarchical clustering of the $-\log 10$ ( $P$-value) analyzed by Mann-Whitney $U$ test for categorical clinical parameters and by Spearman's correlation for continuous clinical parameters. (B) Proportions of different immune cell subsets among severe SARS-CoV-2 ${ }^{+}$patients (severe COVID-19) according to survival at 60 days. Mann-Whitney $U$ test were used. (C) Changes over time in frequencies of selected populations identified as specific to SARS-CoV-2 ${ }^{+}$, between baseline (t0), 24-72h (t1) and 4-7 days (t2). Generalized estimating equations analysis. Each dot represents one patient. ${ }^{*} P<$ 0.05 . 

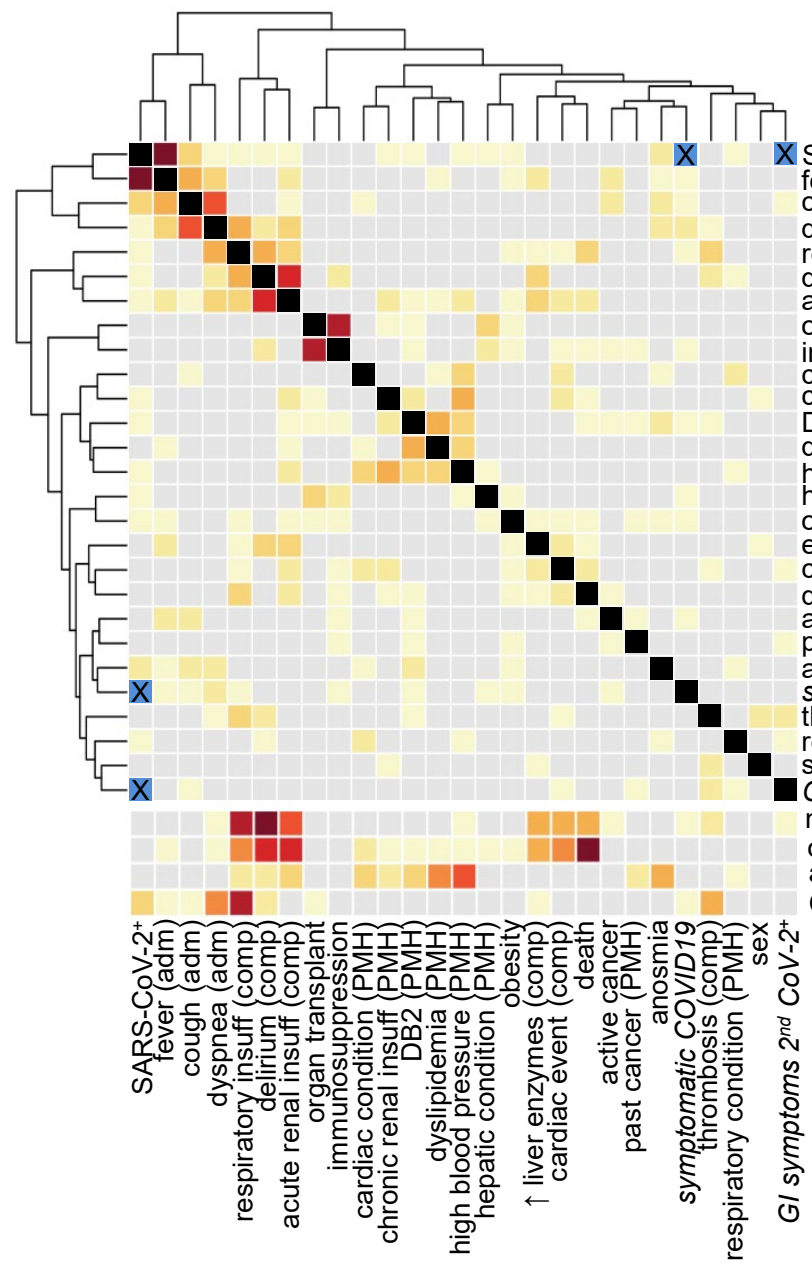

B
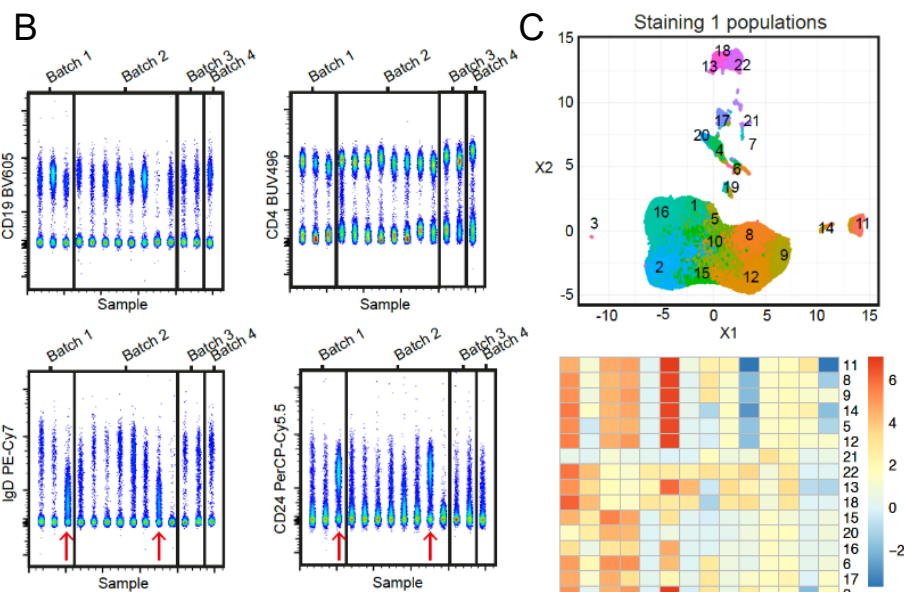

D
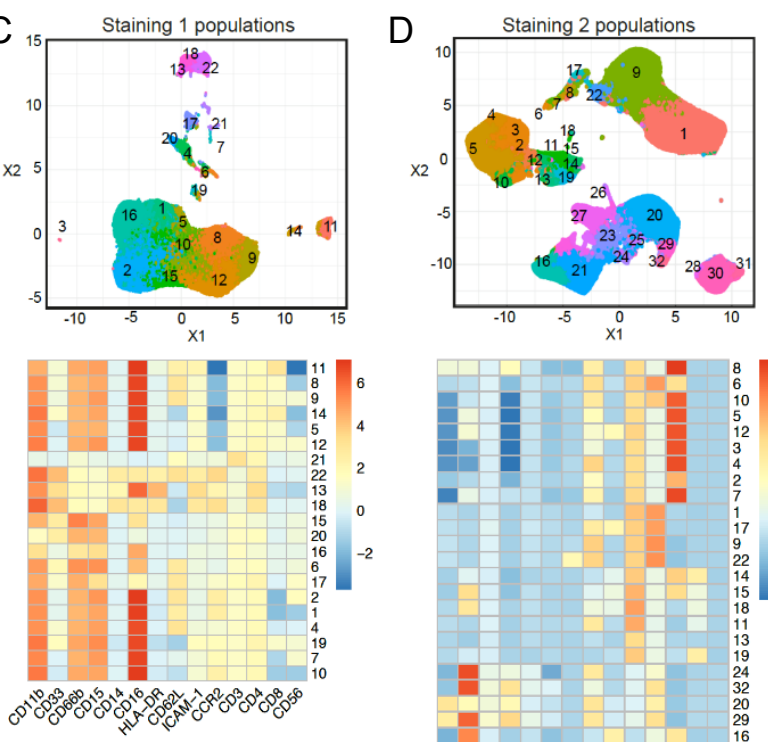

dyslipidemia $(\mathrm{PMH})$
-log10(P-Value)

dyspnea (adm)

respiratory insuff (comp)

delirium (comp)

acute renal insuff (comp)

organ transplant

immunosuppression

cardiac condition (PMH)

DB2 (PMH)

high blood pressure (PMH)

hepatic condition (PMH)

obesity

elevated liver enzymes (comp)

cardiac event (comp)

death

active cancer

past cancer (PMH)

anosmia

symptomatic COVID19

thrombosis (comp)

respiratory condition (PMH)

Gl symptoms $2^{\text {nd }}$ SARS-CoV-2 ${ }^{+}$

mechanical ventilation (days)

outcome 30 days (NIH score)

age

O2 saturation (adm)

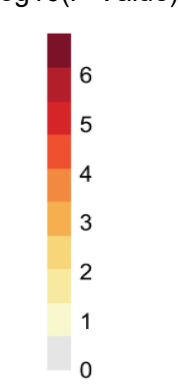

$\mathrm{X}$ : only applicable to SARS-CoV-2 ${ }^{+}$ adm: admission

comp: medical complication

PMH: past medical history

Figure 1. Clinical characteristics and data-driven flow cytometry analysis.

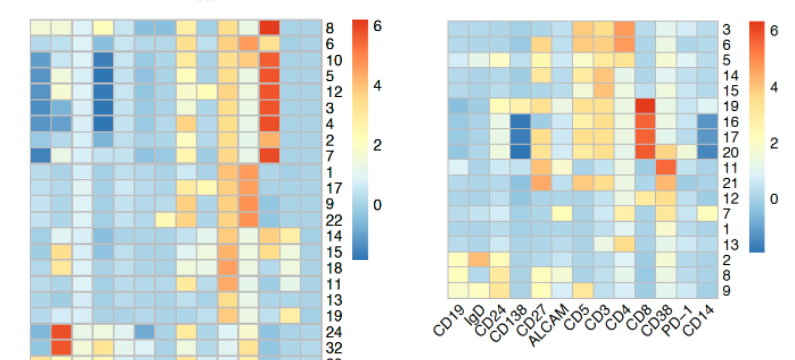

E Staining 3 populations

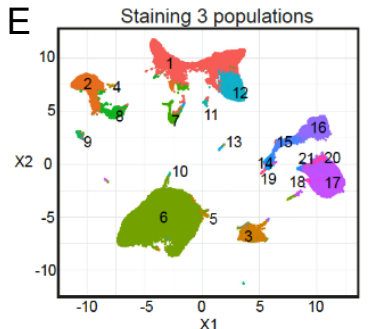

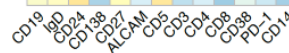

(A) Association among clinical parameters in hospitalized patients as illustrated by heatmap and hierarchical clustering of the -log10 ( $P$ value). Fisher exact test for association of binary variables (upper part), and Wilcoxon rank sum test for association between binary and continuous variables (lower part). Blue squares indicate that only SARS-CoV- $2^{+}$patients were considered for this parameter (B) Representative dot plots of multiple samples acquired in four different batches for CD19-BV605, CD4-BUV496, IgD-PE-Cy7 and CD24PerCP-Cy5.5. Red arrows identify samples from the same individual acquired in two different batches. (C-D-E) Representation of FlowSOM populations on UMAP projection axis and their corresponding heatmap showing geometric mean fluorescence of the different markers for the different subpopulations (unbiased analysis). Cellular markers are indicated on the $x$-axis and population number on the $y$ axis of heatmaps. 

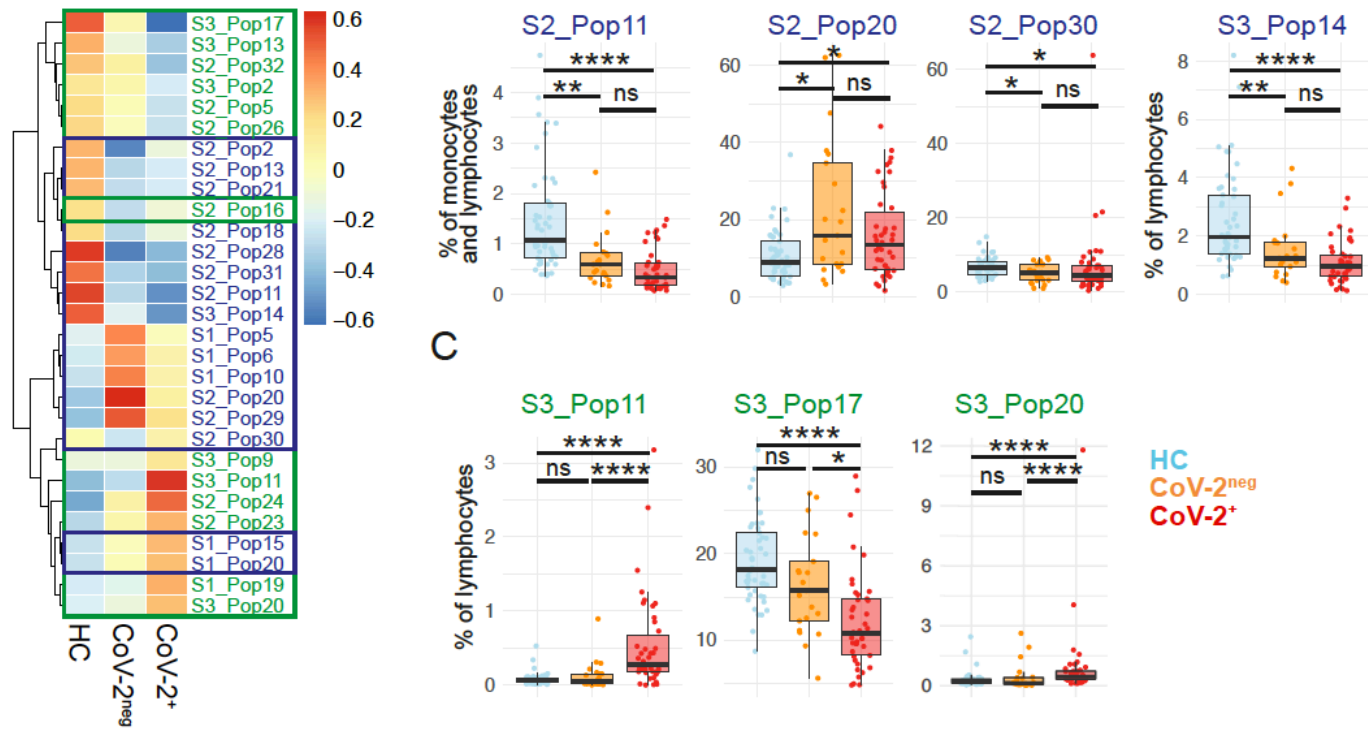

C
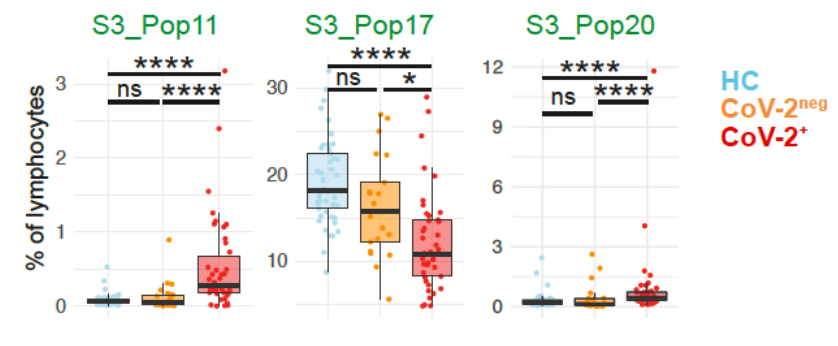

S1 panel

S2 panel

\section{CD16 ${ }^{\text {lo }} \mathrm{CD} 15^{+}$neutrophils \\ CD11b $^{\text {hi }}$ CD62 ${ }^{\text {hi }}$ (CD16 ${ }^{\text {hi }}$ CD15 $^{+}$neutrophils) \\ CD16 ${ }^{\text {hi }} \mathrm{CD} 15^{+}$neutrophils \\ CD11 ${ }^{\text {hi }}$ CD62 $L^{\text {lo }}$ (CD16 ${ }^{\text {hi }}$ CD15 ${ }^{+}$neutrophils) \\ CD11 ${ }^{\text {lo }} \mathrm{CD} 62 \mathrm{~L}^{\text {hi }}\left(\mathrm{CD} 16^{\text {lo }} \mathrm{CD} 15^{+}\right.$neutrophils)}

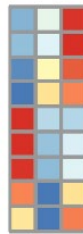

$\mathrm{CD}^{+} 3^{+}\left(\mathrm{CD} 16^{\text {lo }} \mathrm{CD} 15^{+} \mathrm{CD} 11 \mathrm{~b}^{\text {lo }} \mathrm{CD} 62 \mathrm{~L}^{\text {hi }}\right.$ neutrophils ICAM-1 ${ }^{+}\left(\right.$CD16 $^{\text {lo }} \mathrm{CD} 5^{+} \mathrm{CD} 11 \mathrm{~b}^{\text {lo }} \mathrm{CD} 62 \mathrm{~L}^{\text {hi }}$ neutrophils ICAM- $1^{+}\left(\mathrm{CD} 16^{\text {hi }} \mathrm{CD} 15^{+} \mathrm{CD} 11 \mathrm{~b}^{\text {hi }} \mathrm{CD} 62 \mathrm{~L}^{\text {hi }}\right.$ neutrophils)

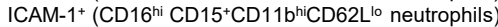

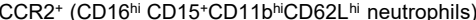
$\mathrm{CCR}^{+}{ }^{\left(\mathrm{CD} 16^{\text {hi }}\right.} \mathrm{CD} 15^{+} \mathrm{CD} 11 \mathrm{~b}^{\text {hi }} \mathrm{CD} 62 \mathrm{~L}^{\text {lo }}$ neutrophils) $\mathrm{HLA}^{-D R^{+}}\left(\mathrm{CD} 16^{\mathrm{lo}} \mathrm{CD} 15+\right.$ neutrophils)

$\mathrm{CD}^{+}{ }^{+}\left(\mathrm{CD} 16^{\text {hi }} \mathrm{CD} 15^{+} \mathrm{CD} 11 \mathrm{~b}^{\text {hi }} \mathrm{CD} 62 \mathrm{~L}^{\text {hi }}\right.$ neutrophils $\mathrm{CD}^{2}{ }^{+}$(CD16 ${ }^{\text {hi }} \mathrm{CD} 15^{+} \mathrm{CD} 11 \mathrm{~b}^{\text {hi }} \mathrm{CD} 62 \mathrm{~L}^{\text {lo }}$ neutrophils)

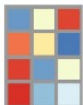

CD14 ${ }^{\text {hi }}$ CD16 ${ }^{+}$monocytes

CD14 ${ }^{\text {hi }}$ CD16 ${ }^{\text {neg }}$ monocytes

$\mathrm{CD}^{+} \mathrm{T}$ cells

CD $14^{\mathrm{lo}} \mathrm{CD} 16^{+}$monocytes

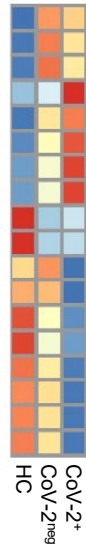

ICAM- $1^{+}\left(\mathrm{CD}^{+} \mathrm{CD}^{+} \mathrm{T}\right.$ cells $)$

$\mathrm{CD}^{2} 6^{+}\left(\mathrm{CD}^{+} \mathrm{CD}^{+} \mathrm{T}\right.$ cells $)$

$\mathrm{ICAM}^{-1^{+}}{ }^{+} \mathrm{CD}^{+} \mathrm{CD}^{+} \mathrm{T}$ cells $)$

$\mathrm{CD} 2 \mathrm{~L}^{+}$(CD14 ${ }^{\mathrm{lo}} \mathrm{CD} 16^{+}$monocytes)

CD11 $\mathrm{b}^{+}\left(\mathrm{CD} 14^{\mathrm{lo}} \mathrm{CD} 16^{+}\right.$monocytes $)$

$\mathrm{CD}^{+} 6^{+}\left(\mathrm{CD}^{+} \mathrm{CD}^{+} \mathrm{T}\right.$ cells $)$

$\mathrm{HLA}^{-D R^{+}}\left(\mathrm{CD}^{+}{ }^{+} \mathrm{CD}^{+} \mathrm{T}\right.$ cells $)$

$\mathrm{CD}_{11 \mathrm{~b}^{+}}$(CD14 ${ }^{\mathrm{hi}} \mathrm{CD} 16^{+}$monocytes)

$\mathrm{HLA}^{-D R^{+}}$(CD14 ${ }^{\text {hi }}$ CD16 ${ }^{+}$monocytes)

HLA-DR $^{+}\left(C D 14^{\text {hi }}\right.$ CD16 ${ }^{\text {neg }}$ monocytes $)$

$\mathrm{CCR2}^{+}$(CD3 $^{+} \mathrm{CD}^{+} \mathrm{T}$ cells)

CCR2 $^{+}$(CD14 ${ }^{\text {hi }}$ CD16 neg monocytes)

$\mathrm{CCR}^{+}{ }^{+} \mathrm{CD}^{+} \mathrm{CD}^{+} \mathrm{T}$ cells $)$

ICAM- $1^{+}\left(\mathrm{CD} 14^{\text {hi }} \mathrm{CD} 16^{\text {neg }}\right.$ monocytes $)$

$\mathrm{CCR2}^{+}\left(\right.$(CD14 $^{\text {hi }} \mathrm{CD}^{\circ}{ }^{+}$monocytes)

ICAM-1 ${ }^{+}\left(\mathrm{CD} 14^{\mathrm{lo}} \mathrm{CD} 16^{+}\right.$monocytes $)$

$\mathrm{HLA}^{-D R^{+}}\left(\mathrm{CD} 14^{10} \mathrm{CD}^{\circ} 6^{+}\right.$monocytes $)$

$\mathrm{CD}^{+}{ }^{+}$(CD14 ${ }^{\mathrm{lo}} \mathrm{CD}^{\circ} 6^{+}$monocytes)

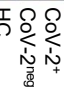

Figure 2. Common and distinct alterations in immune cell populations in SARS-CoV-2 ${ }^{+}$and SARS-CoV-2 ${ }^{\text {neg }}$ hospitalized patients.

(A-C) Data-driven analysis (A) Heatmap showing the median frequencies of immune cell populations differentially regulated in SARSCoV-2 $2^{+}$patients $\left(\mathrm{CoV}-2^{+}\right)$, SARS-CoV-2 ${ }^{\text {neg }}\left(\mathrm{CoV}-2^{\text {neg }}\right)$ and healthy control $(\mathrm{HC})$ samples. (B-C) Box and Whisker plots showing frequencies of dysregulated immune cell populations in (B) CoV-2 ${ }^{+}$(red) compared to CoV-2 ${ }^{\text {neg }}$ (yellow) and $\mathrm{HC}$ (blue) and in (C) hospitalized patients (both CoV-2 $2^{+}$and CoV-2neg) compared to $\mathrm{HC}$ (blue). HC, $n=49$; CoV-2 ${ }^{\text {neg }}, n=21$; CoV-2,$n=42$. Kruskal-Wallis test followed by a Dunn's post hoc-test for multiple pairwise comparisons. ${ }^{*} P<0.05 ;{ }^{* *} P<0.01$; ${ }^{* * *} P<0.0001$. (D) Hypothesis-driven (conventional) analysis. Heatmaps showing the median frequency of immune cell populations identified as significantly altered (adjusted $P<0.05)$ in $\mathrm{CoV}-2^{+}(n=50)$ compared to $\mathrm{HC}(n=49)$ and/or CoV-2neg $(n=22)$ in stain 1 (S1 panel), stain 2 (S2 panel) and stain 3 (S3 panel). Kruskal-Wallis test followed by a Dunn's post hoc-test for multiple pairwise comparisons. Nominal $P$-values were adjusted for multiple testing within each stain, false discovery rate significance threshold set at 0.05 Color scale legends the z-score, across the groups, of sub-population median frequencies. Populations significantly altered $(P<0.05)$ in SARS-CoV-2 ${ }^{+}$compared to HC and to SARS-CoV-2 ${ }^{\text {neg }}$ samples are in bold. 
A

Neutrophils

(\% cells)

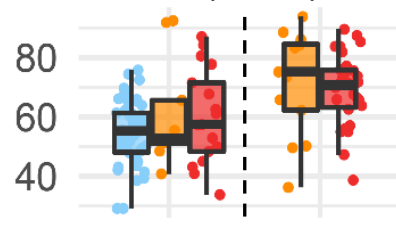

CD16 ${ }^{\text {hi } C D 15 ~}{ }^{+}$

(\% neutrophils)

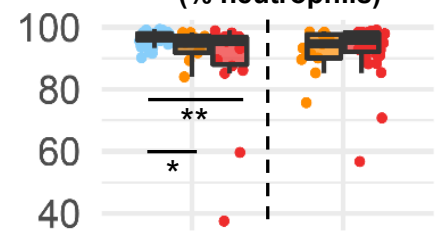

NK cells

(\% cells)

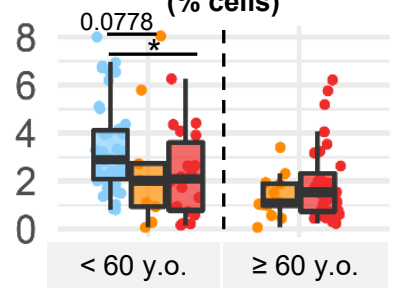

B

Neutrophils

(\% cells)
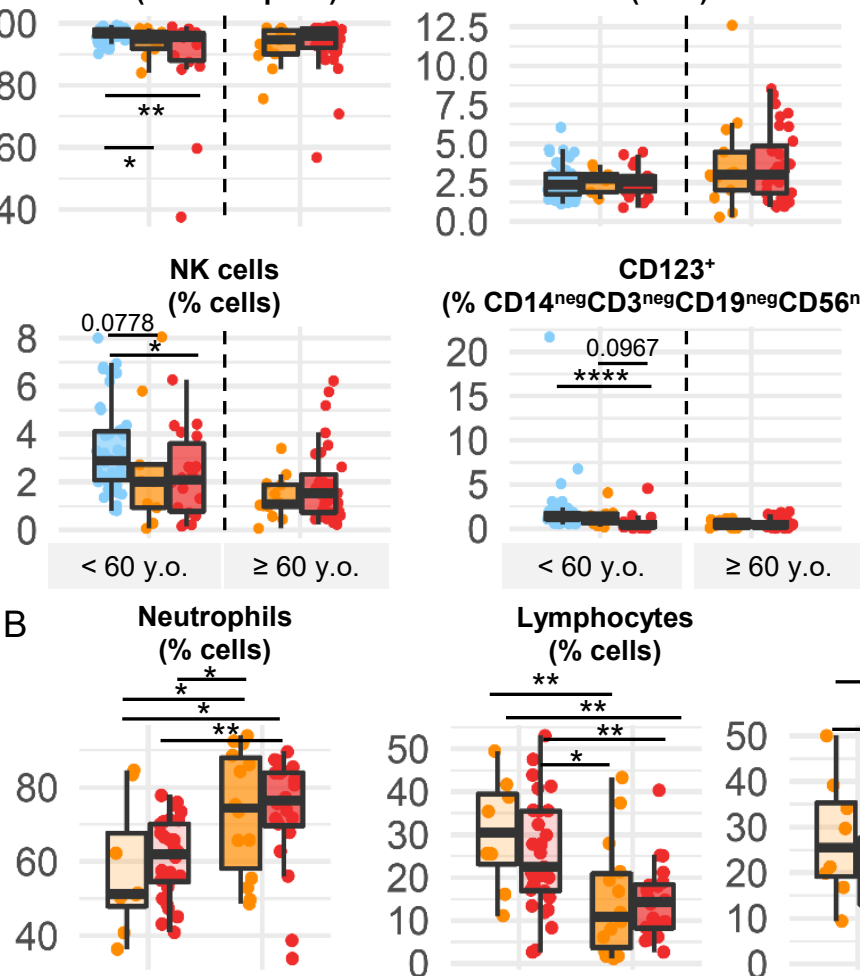

12.5

10.0

7.5

5.0

2.5

0.0

$\mathrm{CD}^{+}$

(\% cells)

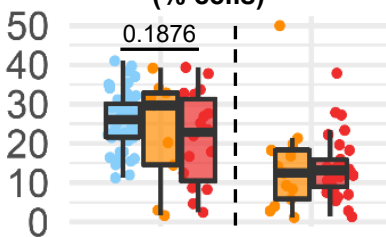

TCRyס

(\% $\left.\mathrm{CD}^{+}\right)$

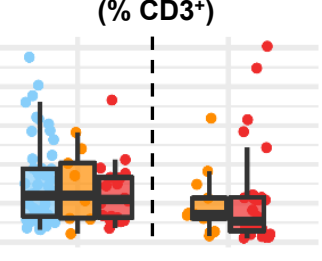

CD11c ${ }^{+}$

(\% CD14 ${ }^{\text {neg }} C D 3^{\text {neg }} C D 19^{\text {neg }}$ CD56 ${ }^{\text {neg }}$ )

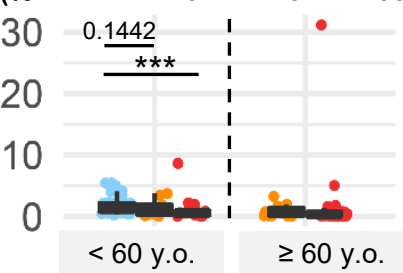

CD3 $^{+}$

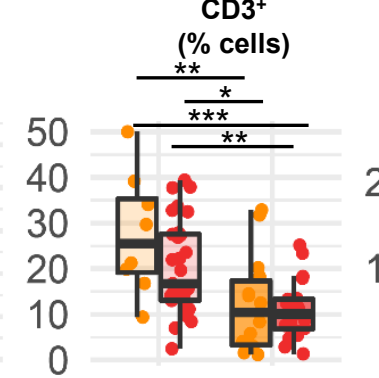

NK cells

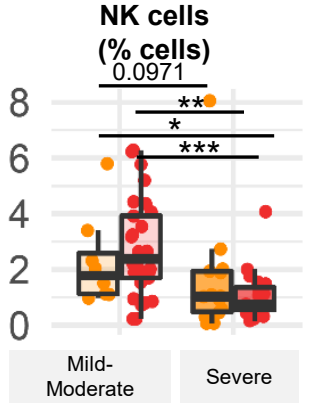

CD19+

(\% cells)
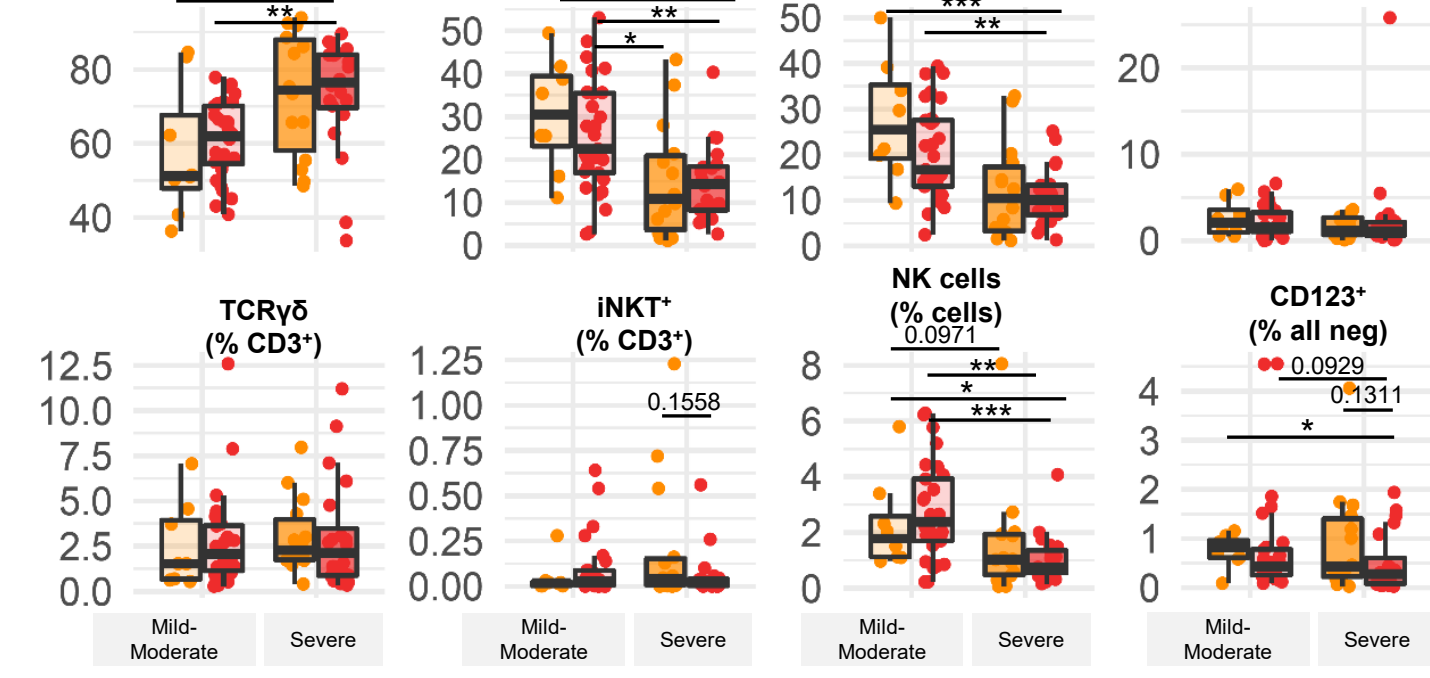

CD123 $^{+}$

(\% all neg)

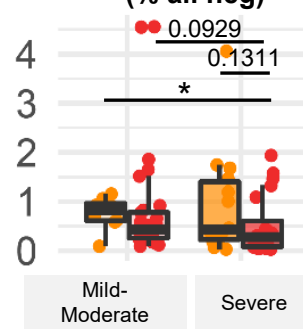

$\mathrm{CD}^{19}{ }^{+}$

(\% cells)

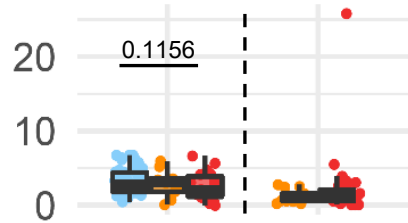

iNKT $^{+}$

$\left(\% \mathrm{CD}^{+}\right)$

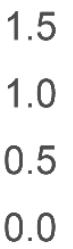

0.0

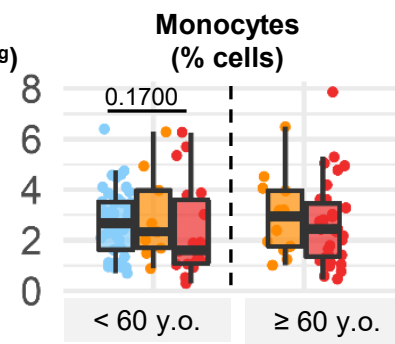

Monocytes

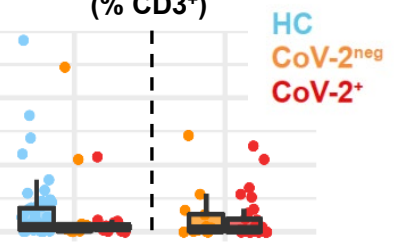

(\% cells)

C $\begin{gathered}\text { Neutrophils } \\ \text { (\% cells) }\end{gathered} \quad \begin{gathered}\text { Lymphocytes } \\ \text { (\% cells })\end{gathered}$

$\mathrm{CD}^{+}$

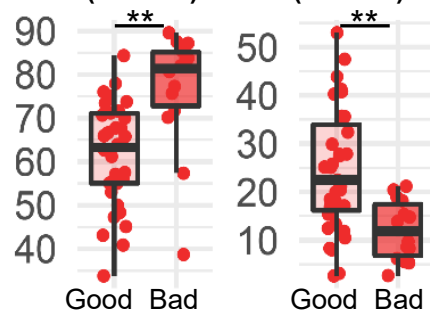

(\% cells)

CD19+

( $\%$ cells)

CD16 $^{\text {hiCD15 }}{ }^{+}$

100

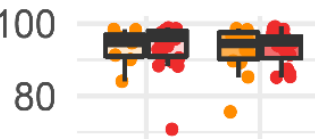

CD16 ${ }^{\text {hiCD15 }}{ }^{+}$

(\% neutrophils)

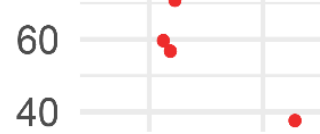

40

CD11c $^{+}$CoV-2nef

(\% all neg) CoV-2+

$30-0.1476$

20

10
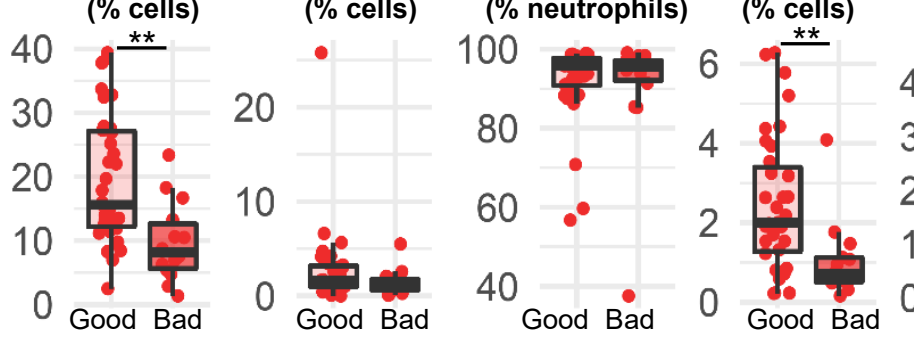

(\% all neg)

CD11c

(\% all neg)

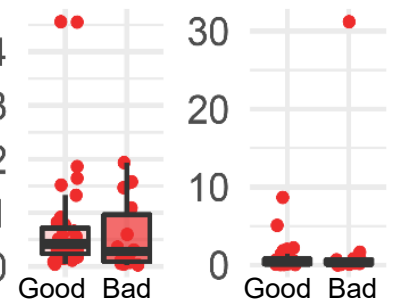

Figure 3. Alterations in immune cell populations commonly observed in SARS-CoV-2 ${ }^{+}$and SARS-CoV-2 ${ }^{\text {neg }}$ hospitalized patients. (AC) Frequencies of different subsets of immune cell populations in peripheral blood (conventional analysis) from SARS-CoV-2 ${ }^{+}\left(\mathrm{CoV}-2^{+}\right.$, red) and SARS-CoV-2 ${ }^{\text {neg }}\left(\mathrm{CoV}-2^{\text {neg }}\right.$, yellow) hospitalized patients and healthy controls $(\mathrm{HC}$, blue $)(\mathbf{A})$ according to age group $(\mathrm{HC}<60$ y.o. $\mathrm{n}=$ 49; CoV-2 ${ }^{\text {neg }}$ hospitalized $<60$ y.o. $n=9$; $\geq 60$ y.o. $n=13$; CoV-2+: $<60$ y.o. $n=20$; $\geq 60$ y.o. $n=30$ ), (B) according to disease severity in hospitalized patients (CoV-2 ${ }^{\text {neg }} \mathrm{mild} /$ moderate disease $n=8$, severe disease $n=14$; CoV-2 $2^{+}$mild/moderate disease $n=29$, severe disease $n=21$ ), and (C) according to clinical outcome at 30 days in SARS-CoV-2 ${ }^{+}$patients (NIH score $\left.5-8, n=36\right)$ vs. (NIH score $\left.1-4, n=14\right)$. Mann-Whitney $U$ test (for $n=2$ categories) and Kruskal-Wallis test (for $n>2$ categories) followed by Dunn's post-hoc test for the multiple pairwise comparisons were used. Each dot represents one donor. ${ }^{\star} P<0.05 ;{ }^{* \star} P<0.01 ;{ }^{* \star *} P<0.001 ;{ }^{\star \star * \star} P<0.0001$. 
$\mathrm{ALCAM}^{+}\left(\mathrm{CD} 14^{+}\right)$

$\mathrm{CD}_{123^{+}}\left(\mathrm{CD} 3^{\text {neg }} \mathrm{CD} 14^{\text {neg }} \mathrm{CD} 19^{\text {neg }} \mathrm{CD} 56^{\text {neg }}\right)$

NK cells (total cells)

ICAM $-1^{+}$(mature neutros)

ICAM-1 ${ }^{+}$(activated neutros)

Neutrophils

$\mathrm{CD5}^{+}\left(\mathrm{CD}^{2} 9^{+}\right)$

$\mathrm{CCR}^{+}\left(\mathrm{CD} 14^{+}\right)$

Monocytes (total cells)

$\mathrm{CD}_{11 \mathrm{c}^{+}}\left(\mathrm{CD}^{+} \mathrm{CD}^{+}\right)$

$\mathrm{CD}^{+}$(total cells)

Lymphocytes (FSC-SSC gate)

$\lg { }^{\text {neg }} C D 27^{\text {neg }}\left(\mathrm{CD} 19^{+}\right)$

iNKT (CD3 $\left.{ }^{+}\right)$

$\mathrm{PD}-1^{+}\left(\mathrm{CD} 4^{+} \mathrm{CD}^{+}\right)$

$\mathrm{CD} 1 \mathrm{a}^{+}\left(\mathrm{CD} 14^{+}\right)$

CD16 ${ }^{\text {hi }} \mathrm{CD} 15^{+}$neutrophils

TCRYठ $\left(\mathrm{CD}^{+}\right)$

Ratio CD4/CD8

$\mathrm{CD}_{11 \mathrm{C}^{+}}\left(\mathrm{CD} 3^{\text {neg }} \mathrm{CD} 14^{\text {neg }} \mathrm{CD} 19^{\text {neg }} \mathrm{CD} 56^{\text {neg }}\right)$

CD19+ (total cells)

$\mathrm{CD}^{2} 8^{+}\left(\mathrm{CD}^{+} \mathrm{CD}^{+}\right)$

CD14 hi CD16+ monocytes

$\mathrm{CD}^{+}{ }^{+}$(neutrophils)

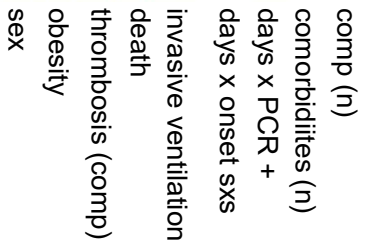

comp: medical complication sxs: symptoms

$-\log 10(P-V a l u e)$

3

2

1.5

1

$\mathrm{n}$ : number

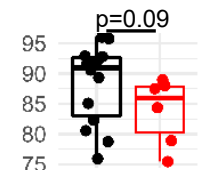

ICAM-1+

(\% mature neutros)

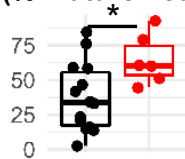

ICAM-1 ${ }^{+}$

(\% activated neutros)

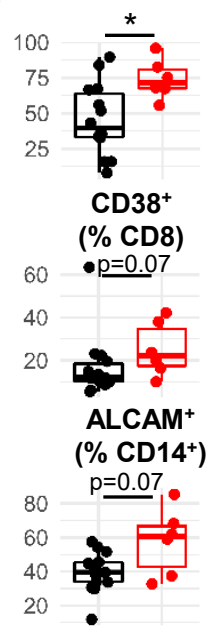

C

$\mathrm{CCR2}^{+}$

(\% CD14 ${ }^{+}$)

NIH 5-8

Good outcome

NIH 1-4

Bad outcome

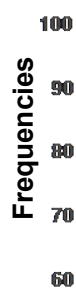

(1)
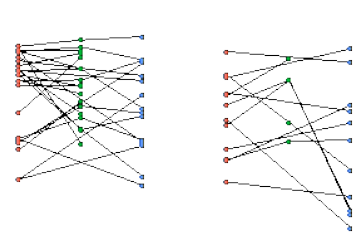

to $-11-12$

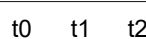

\section{CD38+}

$\left(\% \mathrm{CD}^{+}\right)$

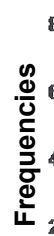

\section{(\% CD16 ${ }^{\text {hi CD15 }}{ }^{+}$CD11b ${ }^{\text {hi }}$ CD62 ${ }^{\text {hi }}$ )}

NIH 5-8
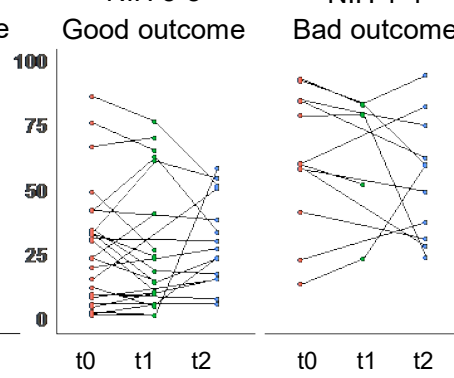

NIH 1-4

Bad outcome

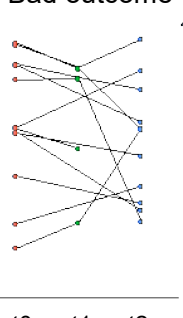

ICAM-1+

(\% CD16 ${ }^{\text {hi CD15 }}{ }^{+}$CD11b ${ }^{\text {hi CD62 }}{ }^{\text {lo }}$ )

\section{NIH 5-8}

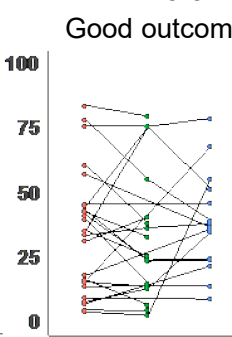

to t1 t2

$\mathrm{NIH} \mathrm{1-4}$

Bad outcome

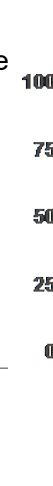

(\% CD19+)

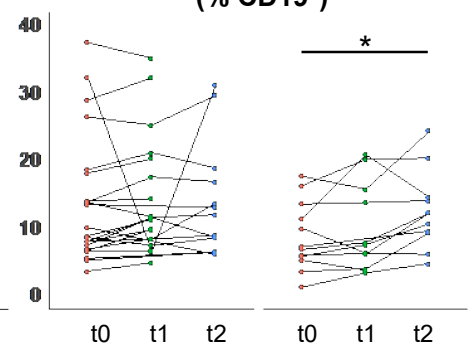

ALCAM $^{+}$

(\% CD14 ${ }^{+}$)

NIH 5-8

NIH 1-4

Good outcome Bad outcome
由 Survivor

EDeceased

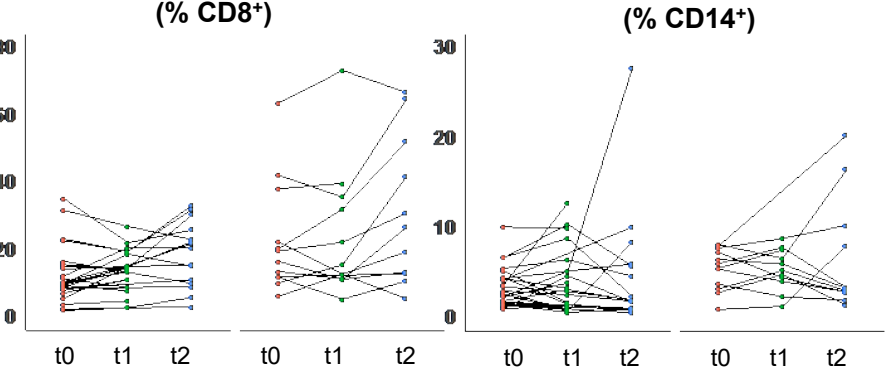

Figure 5. Association between clinical parameters and longitudinal analysis of immune cell populations altered in SARS-CoV-2 ${ }^{+}$ patients. (A) Association between immune cell subsets and clinical parameters in SARS-CoV-2 ${ }^{+}$patients as illustrated by heatmap and hierarchical clustering of the -log10 ( $P$-value) analyzed by Mann-Whitney $U$ test for categorical clinical parameters and by Spearman's correlation for continuous clinical parameters. (B) Proportions of different immune cell subsets among severe SARS-CoV-2 ${ }^{+}$patients (severe COVID-19) according to survival at 60 days. Mann-Whitney $U$ test were used. (C) Changes over time in frequencies of selected populations identified as specific to SARS-CoV-2+, between baseline (t0), 24-72h (t1) and 4-7 days (t2). Generalized estimating equations analysis. Each dot represents one patient. ${ }^{*} P<0.05$. 
Table 1: Baseline characteristics of population

\begin{tabular}{|c|c|c|c|c|}
\hline Baseline clinical characteristics & $\begin{array}{l}\text { Healthy controls } \\
(n=49)\end{array}$ & $\begin{array}{l}\text { Hospitalized } \\
\text { SARS-CoV-2 } \\
\text { (n }=22)\end{array}$ & $\begin{array}{l}\text { Hospitalized } \\
\text { SARS-CoV-2 } \\
(\mathrm{n}=50)\end{array}$ & $\begin{array}{l}\text { Statistical analysis } \\
\text { (SARS-CoV-2 } \\
\text { SARS-CoV2 }^{+} \text {) }\end{array}$ \\
\hline Age, mean years (SD) & $38.7(11.9)$ & $58.4(17.2)$ & $59.5(14.6)$ & $\# p=0.9347$ \\
\hline Male sex, n (\%) & $20(40.8)$ & $15(68.2)$ & $30(60.0)$ & ${ }^{+} p=0.6022$ \\
\hline$<60$ y.o., $\mathrm{n}(\%)$ & $49 / 49(100)$ & $9 / 22(40.9)$ & $20 / 50(40)$ & ${ }^{+} p>0.9999$ \\
\hline \multicolumn{5}{|l|}{ Co-morbidities and past medical history } \\
\hline BMI over $25.0, \mathrm{n}(\%)$ & ND & $13 / 22(59.1)$ & $38 / 46(82.6)$ & ${ }^{+} p=0.0698$ \\
\hline Chronic renal insufficiency, n (\%) & ND & $1 / 22(4.5)$ & $11 / 50(22.0)$ & ${ }^{+} p=0.0904$ \\
\hline Cardiac condition, n (\%) & ND & $5 / 22(22.7)$ & $9 / 50(18.0)$ & ${ }^{+} p=0.7485$ \\
\hline Respiratory condition, $\mathrm{n}(\%)$ & ND & $7 / 22(31.8)$ & $7 / 50(14.0)$ & ${ }^{+} p=0.1073$ \\
\hline Hepatic condition, $\mathrm{n}(\%)$ & ND & $3 / 22(13.6)$ & $1 / 50(2.0)$ & ${ }^{+} p=0.0820$ \\
\hline High blood pressure, n (\%) & ND & $11 / 22(50.0)$ & $33 / 50(66.0)$ & ${ }^{+} p=0.2939$ \\
\hline Dyslipidemia, n (\%) & ND & $7 / 22(31.8)$ & $22 / 50(44.0)$ & ${ }^{+} p=0.4362$ \\
\hline Diabetes type $1, \mathrm{n}(\%)$ & ND & $0 / 22(0)$ & $1 / 50(2.0)$ & ${ }^{+} p>0.9999$ \\
\hline Diabetes type 2, n (\%) & ND & $6 / 22(27.2)$ & $24 / 50(48.0)$ & ${ }^{+} p=0.1242$ \\
\hline $\begin{array}{l}\text { Co-morbidities total, } \\
\text { n (excluding obesity) (\%) }\end{array}$ & ND & $\begin{array}{l}0: 6 / 22(27.2) \\
1-2: 9 / 22(40.9) \\
\geq 3: 7 / 22(31.8)\end{array}$ & $\begin{array}{l}0: 11 / 50(22.0) \\
1-2: 17 / 50(34.0) \\
\geq 3: 22 / 50(44.0) \\
\end{array}$ & ${ }^{\ddagger} p=0.6235$ \\
\hline Organ transplant, n (\%) & ND & $3 / 22(13.6)$ & $4 / 50(8.0)$ & ${ }^{+} p=0.6678$ \\
\hline Active cancer, n (\%) & $\mathrm{ND}$ & $3 / 22(13.6)$ & $3 / 50(6.0)$ & ${ }^{+} p=0.3612$ \\
\hline Cancer history, n (\%) & ND & $4 / 22(18.2)$ & $4 / 50(8.0)$ & ${ }^{+} p=0.2372$ \\
\hline $\begin{array}{l}\text { Active infection except COVID-19, } n \\
(\%)\end{array}$ & ND & $10 / 22(45.5)$ & $16 / 50(32.0)$ & $+p=0.2979$ \\
\hline
\end{tabular}

SD: standard deviation; $\mathrm{n}$ : number of patients in specified category; ND: not determined; y.o.: years old;

+ Fisher's exact test; \# Mann-Whitney $U$ test; $¥$ Chi-squared test.

Table 2: Clinical data related to hospitalization in SARS-CoV-2 ${ }^{\text {neg }}$ and SARS-CoV-2 ${ }^{+}$patients

\begin{tabular}{|c|c|c|c|}
\hline Clinical data-Hospitalization & $\begin{array}{l}\text { SARS-CoV-2 } \\
(\mathrm{n}=22)\end{array}$ & $\begin{array}{l}\text { SARS-CoV-2 } \\
(n=50)\end{array}$ & Statistical analysis \\
\hline \multicolumn{4}{|l|}{ Outcome and severity } \\
\hline Symptomatic COVID-19, n (\%) & NA & $47 / 50(94)$ & NA \\
\hline Severe disease (high flow or invasive ventilation), $\mathrm{n}(\%)$ & $14 / 22(63.6)$ & $21 / 50(42)$ & ${ }^{+} p=0.1255$ \\
\hline$<60 y .0$. in mild-moderate disease, $\mathrm{n}(\%)$ & $3 / 8(37.5)$ & $12 / 29(41.4)$ & ${ }^{+} p>0.9999$ \\
\hline$<60 y .0$. in severe disease, $\mathrm{n}(\%)$ & $6 / 14(42.9)$ & $8 / 21(38.1)$ & ${ }^{+} p>0.9999$ \\
\hline Thirty-day outcome (NIH 8 point-scale), mean (SD) & $6.3(2.3)$ & $5.7(2.5)$ & ${ }^{+} p=0.3724$ \\
\hline $\begin{array}{l}\text { Thirty-day outcome: ambulatory (7-8 on NIH } 8 \text { point-scale), } \\
\text { n (\%) }\end{array}$ & $16 / 22(72.7)$ & $27 / 50(54.0)$ & ${ }^{+} p=0.1930$ \\
\hline $\begin{array}{l}\text { Thirty-day outcome: unfavorable (1-4 on NIH } 8 \text { point-scale), } \\
\mathrm{n}(\%)\end{array}$ & $5 / 22(22.7)$ & $14 / 50(28)$ & ${ }^{+} p=0.7751$ \\
\hline$<60 y .0$. in thirty-day outcome: unfavorable, $n(\%)$ & $2 / 5(40)$ & $3 / 14(21.4)$ & ${ }^{+} p=0.5696$ \\
\hline Thirty-day outcome: deceased, $\mathrm{n}(\%)$ & $2 / 22(9.1)$ & $3 / 50(6.0)$ & ${ }^{+} p=0.6379$ \\
\hline Sixty-day outcome: deceased, n (\%) & $2 / 22(9.1)$ & $7 / 50(14.0)$ & ${ }^{+} p=0.7125$ \\
\hline Invasive ventilation during hospitalization, $\mathrm{n}(\%)$ & $10 / 22(45.5)$ & $21 / 50(42.0)$ & ${ }^{+} p=0.8017$ \\
\hline Total duration of invasive ventilation, median day (range) & $4.5(1-20)$ & $24.5(8-57)$ & $\# p<0.0001$ \\
\hline \multicolumn{4}{|l|}{ Medical complications during hospitalization } \\
\hline $\begin{array}{l}\text { Thrombo-embolic event excluding admission for NSTEMI, } \\
\mathrm{n}(\%)\end{array}$ & $2 / 22(9.1)$ & $7 / 50(14.0)$ & ${ }^{+} p=0.7125$ \\
\hline Acute renal insufficiency, $\mathrm{n}(\%)$ & $3 / 22(13.6)$ & $18 / 50(36.0)$ & ${ }^{+} p=0.0896$ \\
\hline Cardiac event, $\mathrm{n}(\%)$ & $5 / 22(22.7)$ & $12 / 50(24.0)$ & ${ }^{+} p>0.9999$ \\
\hline Respiratory insufficiency, $\mathrm{n}(\%)$ & $9 / 22(40.9)$ & $31 / 50(62.0)$ & ${ }^{+} p=0.1251$ \\
\hline Elevated liver enzymes, $\mathrm{n}(\%)$ & $8 / 22(36.4)$ & $23 / 50(46.0)$ & ${ }^{+} p=0.6061$ \\
\hline Delirium, n (\%) & $2 / 22(9.1)$ & $20 / 50(40.0)$ & ${ }^{+} p=0.0115$ \\
\hline Complications total, $\mathrm{n}(\%)$ & $\begin{array}{l}0: 5 / 22(22.7) \\
1-2: 14 / 22(63.6) \\
\geq 3: 3 / 22(13.6)\end{array}$ & $\begin{array}{l}0: 12 / 50(24.0) \\
1-2: 14 / 50(28.0) \\
\geq 3: 24 / 50(48.0)\end{array}$ & ${ }^{\ddagger} p=0.0074$ \\
\hline
\end{tabular}

n: number of patients in specified category; y.o.: years old; NA: not applicable

+ Fisher's exact test; \# Mann-Whitney U test; $¥$ Chi-squared test 
Table 3: Summary of identified alterations in subsets of immune cells according to status, severity, outcome and mortality

\begin{tabular}{|c|c|c|c|c|}
\hline 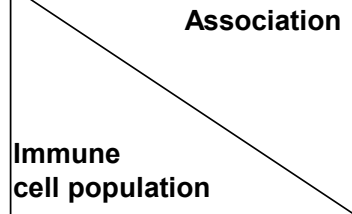 & $\begin{array}{c}\text { Status } \\
\left(\mathrm{CoV}-2^{+} \text {vs. }\right. \\
\left.\text { CoV-2 } 2^{\text {neg }}\right)\end{array}$ & $\begin{array}{c}\text { Severity } \\
\text { COVID-19 } \\
\left.(\text { CoV-2 })^{+}\right)\end{array}$ & $\begin{array}{l}\text { Outcome } \\
\text { at } 30 \text { days } \\
\left.\text { (CoV-2 })^{2}\right)\end{array}$ & $\begin{array}{l}\text { Mortality } \\
\text { at } 60 \text { days } \\
(\text { severe } \\
\left.\text { CoV }-2^{+}\right)\end{array}$ \\
\hline Neutrophils & $\leftrightarrow$ & $\uparrow$ & $\uparrow$ & $\nearrow$ \\
\hline Lymphocytes & $\leftrightarrow$ & $\downarrow$ & $\downarrow$ & $\searrow$ \\
\hline CD3 $^{+} \mathrm{T}$ lymphocytes & $\leftrightarrow$ & $\downarrow$ & $\downarrow$ & $\searrow$ \\
\hline CD19 $^{+}$B lymphocytes & $\leftrightarrow$ & $\leftrightarrow$ & $\leftrightarrow$ & $\leftrightarrow$ \\
\hline Monocytes & $\leftrightarrow$ & $\downarrow$ & $\searrow$ & $\downarrow$ \\
\hline NK cells & $\leftrightarrow$ & $\downarrow$ & $\downarrow$ & $\searrow$ \\
\hline iNKT & $\leftrightarrow$ & $\leftrightarrow$ & $\leftrightarrow$ & $\leftrightarrow$ \\
\hline TCRyס & $\leftrightarrow$ & $\leftrightarrow$ & $\leftrightarrow$ & $\searrow$ \\
\hline $\begin{array}{l}\text { PD- } 1^{+} \text {CD4 }^{+} \text {T } \\
\text { lymphocytes }\end{array}$ & $\uparrow$ & $\leftrightarrow$ & $\uparrow$ & $\leftrightarrow$ \\
\hline $\begin{array}{l}\text { CD11c }^{+} \text {CD8 }^{+} \mathrm{T} \\
\text { lymphocytes }\end{array}$ & $\downarrow$ & $\searrow$ & $\leftrightarrow$ & $\leftrightarrow$ \\
\hline $\begin{array}{l}\text { CD38 }{ }^{+} \mathrm{CD}^{+} \mathrm{T} \\
\text { lymphocytes }\end{array}$ & $\uparrow$ & $\nearrow$ & $\uparrow$ & $\uparrow$ \\
\hline $\begin{array}{l}\text { CD27 }{ }^{\text {neg }} / g D^{\text {neg }} \\
\text { B lymphocytes }\end{array}$ & $\uparrow$ & $\leftrightarrow$ & $\leftrightarrow$ & $\leftrightarrow$ \\
\hline $\mathrm{CD}^{+} \mathrm{CD} 19^{+}$ & $\searrow$ & $\downarrow$ & $\searrow$ & $\leftrightarrow$ \\
\hline CD16 ${ }^{\text {hi }}$ CD15 ${ }^{+}$neutrophils & $\leftrightarrow$ & $\leftrightarrow$ & $\leftrightarrow$ & $\leftrightarrow$ \\
\hline $\begin{array}{l}\text { CD123 }{ }^{+} \text {in CD14 } \\
\text { myeloid }\end{array}$ & $\leftrightarrow$ & $\searrow$ & $\leftrightarrow$ & $\searrow$ \\
\hline $\begin{array}{l}\text { CD11c }{ }^{+} \text {in CD14 }{ }^{\text {neg }} \\
\text { myeloid }\end{array}$ & $\leftrightarrow$ & $\leftrightarrow$ & $\leftrightarrow$ & $\leftrightarrow$ \\
\hline CD38+ promyelocytes & $\uparrow$ & $\leftrightarrow$ & $\leftrightarrow$ & $\uparrow$ \\
\hline Mature neutrophils & $\uparrow$ & $\leftrightarrow$ & $\searrow$ & $\leftrightarrow$ \\
\hline $\begin{array}{l}\text { ICAM }-1^{+} \text {in mature and } \\
\text { activated neutrophils }\end{array}$ & $\nearrow$ & $\uparrow$ & $\uparrow$ & $\uparrow$ \\
\hline CD14 ${ }^{\mathrm{hi}} \mathrm{CD} 16^{+}$monocytes & $\uparrow$ & $\leftrightarrow$ & $\leftrightarrow$ & $\downarrow$ \\
\hline ALCAM $^{+}$monocytes & $\uparrow$ & $\uparrow$ & $\lambda$ & $\pi$ \\
\hline CCR2 $^{+}$monocytes & $\downarrow$ & $\leftrightarrow$ & $\downarrow$ & $\searrow$ \\
\hline $\mathrm{CD} \mathrm{a}^{+}$monocytes & $\uparrow$ & $\uparrow$ & $\nearrow$ & $\leftrightarrow$ \\
\hline
\end{tabular}

CoV-2+: SARS-CoV-2+; CoV-2neg: SARS-CoV-2neg 